\title{
Additive manufacturing of an elastic poly(ester)urethane for cartilage tissue engineering
}

Citation for published version (APA):

Camarero-Espinosa, S., Calore, A., Wilbers, A., Harings, J., \& Moroni, L. (2020). Additive manufacturing of an elastic poly(ester)urethane for cartilage tissue engineering. Acta Biomaterialia, 102, 192-204. https://doi.org/10.1016/j.actbio.2019.11.041

Document status and date:

Published: 15/01/2020

DOI:

10.1016/j.actbio.2019.11.041

Document Version:

Publisher's PDF, also known as Version of record

Document license:

Taverne

Please check the document version of this publication:

- A submitted manuscript is the version of the article upon submission and before peer-review. There can be important differences between the submitted version and the official published version of record.

People interested in the research are advised to contact the author for the final version of the publication, or visit the DOI to the publisher's website.

- The final author version and the galley proof are versions of the publication after peer review.

- The final published version features the final layout of the paper including the volume, issue and page numbers.

Link to publication

\footnotetext{
General rights rights.

- You may freely distribute the URL identifying the publication in the public portal. please follow below link for the End User Agreement:

www.umlib.nl/taverne-license

Take down policy

If you believe that this document breaches copyright please contact us at:

repository@maastrichtuniversity.nl

providing details and we will investigate your claim.
}

Copyright and moral rights for the publications made accessible in the public portal are retained by the authors and/or other copyright owners and it is a condition of accessing publications that users recognise and abide by the legal requirements associated with these

- Users may download and print one copy of any publication from the public portal for the purpose of private study or research.

- You may not further distribute the material or use it for any profit-making activity or commercial gain

If the publication is distributed under the terms of Article $25 \mathrm{fa}$ of the Dutch Copyright Act, indicated by the "Taverne" license above, 
Full length article

\title{
Additive manufacturing of an elastic poly(ester)urethane for cartilage tissue engineering
}

\author{
Sandra Camarero-Espinosa ${ }^{\mathrm{a}, \mathrm{b}, *}$, Andrea Calore $^{\mathrm{a}, \mathrm{c}}$, Arnold Wilbers $^{\mathrm{d}}$, Jules Harings ${ }^{\mathrm{c}}$, \\ Lorenzo Moroni ${ }^{\mathrm{a}, *}$ \\ ${ }^{a}$ Complex Tissue Regeneration Department, MERLN Institute for Technology-inspired Regenerative Medicine, Maastricht University, P.0. Box 616, 6200 MD \\ Maastricht, the Netherlands \\ b Polyganics, Rozenburglaan 15A, 9727 DL Groningen, the Netherlands \\ ${ }^{c}$ Aachen Maastricht Institute for Biobased Materials, Maastricht University, P.O. Box 616, 6200 MD Maastricht, the Netherlands \\ ${ }^{\mathrm{d}}$ DSM Materials Science Center, P.O. Box 1171, 6160 MD Geleen, the Netherlands
}

\section{A R T I C L E I N F O}

\section{Article history:}

Received 4 September 2019

Revised 20 November 2019

Accepted 21 November 2019

Available online 26 November 2019

\section{Keywords:}

Cartilage tissue engineering

Fused deposition modeling

Poly(ester)urethane

\begin{abstract}
A B S T R A C T
Although a growing knowledge on the field of tissue engineering of articular cartilage exists, reconstruction or in-vitro growth of functional hyaline tissue still represents an unmet challenge. Despite the simplicity of the tissue in terms of cell population and absence of innervation and vascularization, the outstanding mechanical properties of articular cartilage, which are the result of the specificity of its extra cellular matrix (ECM), are difficult to mimic. Most importantly, controlling the differentiation state or phenotype of chondrocytes, which are responsible of the deposition of this specialized ECM, represents a milestone in the regeneration of native articular cartilage. In this study, we fabricated fused deposition modelled (FDM) scaffolds with different pore sizes and architectures from an elastic and biodegradable poly(ester)urethane (PEU) with mechanical properties that can be modulated by design, and that ranged the elasticity of articular cartilage. Cell culture in additive manufactured 3D scaffolds exceeded the chondrogenic potential of the gold-standard pellet culture. In-vitro cell culture studies demonstrated the intrinsic potential of elastic (PEU) to drive the re-differentiation of de-differentiated chondrocytes when cultured in-vitro, in differentiation or basal media, better than pellet cultures. The formation of neo-tissue was assessed as a high deposition of GAGs and fibrillar collagen II, and a high expression of typical chondrogenic markers. Moreover, the collagen II / collagen I ratio commonly used to evaluate the differentiation state of chondrocytes (ratio $>1$ being chondrocytes and, ratio $<0$ being de-differentiated chondrocytes) was higher than 5.
\end{abstract}

\section{Statement of significance}

Tissue engineering of articular cartilage requires material scaffolds capable of driving the deposition of a coherent and specific ECM representative of articular cartilage. Materials explored so far account for low mechanical properties (hydrogels), or are too stiff to mimic the elasticity of the native tissue (traditional polyesters). Here, we fabricated 3D fibrous scaffolds via FDM with a biodegradable poly(ester)urethane. The compressive Young's modulus and elastic limit of the scaffolds can be tuned by designed, mimicking those of the native tissue. The designed scaffolds showed an intrinsic potential to drive the formation of a GAG and collagen II rich ECM, and to drive a stable chondrogenic cell phenotype.

(c) 2019 Acta Materialia Inc. Published by Elsevier Ltd. All rights reserved.

\section{Introduction}

Articular cartilage is an avascular and non-innervated tissue present at the ends of long bones that serves as an interface,

\footnotetext{
* Corresponding authors.

E-mail addresses: espinosa@maastrichtuniversity.nl (S. Camarero-Espinosa), l.moroni@maastrichtuniversity.nl (L. Moroni).
}

allows for frictionless movement, and supports the applied loads on the different articulations [1]. Cartilage is unable to selfheal onto functional tissue upon damage or diseases such as osteoarthritis. The mainstay clinical procedures to regenerate articular cartilage are based on the expansion in-vitro and implantation thereafter of autologous chondrocytes (known as $\mathrm{ACl}$ or MACI when combined with a matrix support), microfracture techniques that aim at recruiting stem cells from bone marrow to 
repopulate the damaged area, or direct implantation of autologous tissue explants such as mosaicplasty [2,3]. Although these procedures represent an immediate relieve of symptoms such as pain during articulation and reduced mobility of the patient, long-term outcomes point-out to the formation of cartilaginous tissue more representative of fibrocartilage, with unpaired mechanical properties, extracellular matrix (ECM) composition and cell phenotype, resulting in failure and often the need for a second treatment.

Tissue regeneration of functional articular cartilage with the aid of a material support that drives the differentiation of the cells, and therefore the deposition of a coherent and functional ECM capable of supporting the loads applied on the knee, appears as an ideal solution. Due to the aforementioned intrinsic tissue properties (non-innervated and avascular) and the presence of a single cell type within, the chondrocyte, articular cartilage was believed to be one of the first tissues to be successfully engineered [4]. However, due to the non-proliferative character of chondrocytes within the native tissue and the outstanding mechanical properties of hyaline cartilage - high compressive modulus, elasticity and resilience - regeneration or in-vitro formation of hyaline cartilage remains still elusive. Finding the appropriate material and fabrication technique that leads to a scaffold capable of driving cell differentiation while accounting for adequate mechanical properties has been the center of extensive research in the last decades [5-7].

Articular cartilage accounts for a complex layered structure rich in collagen II and glycosaminoglycans (GAGs) [5]. Collagens within cartilage form a tight network that varies in orientation and type along the tissue. Sulfated GAGs and carboxylic groups of hyaluronan impart a fixed negative charge to the tissue that entraps water molecules and is responsible of the osmotic pressure generated. This water entrapment, together with the confinement produced by the collagen network results on the outstanding properties of the tissue $[8,9]$.

Chondrocytes of articular cartilage account for a defined phenotype characterized by the expression of collagen II, aggrecan, and the transcription factor trio Sox-9, Sox-5 and Sox-6 with low levels of collagen I, IX and X and runt-related transcription factor 2 (RunX2) [10]. This characteristic phenotype determines the specific ECM deposited by chondrocytes, responsible of the outstanding mechanical properties of the tissue. Culture and expansion of chondrocytes in 2-dimensional (2D) or stiff 3-dimensional (3D) substrates leads to an increased cell spread area, formation of defined Actin filaments and final de-differentiation of the cells towards hypertrophic phenotypes. These are characterized by a higher expression of osteogenic markers such as collagen I, X and RunX2 and the deposition of an ECM reach in collagen I. Thus, the use of naturally derived or synthetic hydrogel scaffolds or pellet cultures that maintain the rounded morphology of the cells and support the formation of coherent hyaline-like cartilage have been extensively explored [11-16]. Although these represent an ideal platform to study the formation and development of the osteochondral interface, the mechanical properties are far below those of the native tissue $[17,18]$. In order to increase the mechanical properties of traditional hydrogels several approaches such as their reinforcement with polyester-based fibrous electrospun [19,20], melt-electrospun $[12,21]$ or woven scaffolds [22-25] or, the fabrication of interpenetrating networks $[26,27]$ have been developed. Stiffer synthetic materials such as poly(lactic acid) (PLA), polycaprolactone (PCL), poly(lactide-co-glycolide) (PLGA) or poly(ethylene oxide) terephthalate/poly(butylene) terephthalate (PEOT/PBT) have been studied as support materials for tissue engineering of articular cartilage on the shape of porous sponges, electrospan fibrous meshes and additive manufactured fibrous scaffolds alone [28-35]. Lately, Woodfield and co-workers also developed a 3D bioassembly platform in which cartilage micro-tissues of pre-differentiated chondrocyte-laden hydrogels can be precisely inserted into fused deposition modelled scaffolds [36]. While these represent robust platforms to engineer articular cartilage and are capable of supporting the loads applied on the knee, the elasticity of the scaffolds appears to be limited and intrinsic to the materials used [37,38].

Biodegradable and elastomeric poly(ester)urethanes have emerged as potential materials for soft tissue engineering were high resilience is desired. Their application for tissue regeneration of cardiac, vasculature and cartilage models has been lately studied by fabrication of scaffolds via electrospinning, salt-leaching or thermally induced phase separation systems from solution [39-43]. However, the processing of these biomaterials via additive manufacturing into resilient but stiffer scaffolds has appeared limited due to their limited processability [44]. Gorna et al. described a combined salt leaching-phase inversion process for the fabrication of porous PEU scaffolds that was later exploited for cartilage tissue engineering with primary chondrocytes. A progressive increase of GAG and collagen deposition was detected over a 42 day culture period $[45,46]$. Stoddart and co-workers further studied the potential use of PEU scaffolds, fabricated as described by Gorna and co-workers, for the differentiation of fibrinogen suspended human mesenchymal stem cells (hMSCs) towards chondrogenic phenotypes [47]. After 14 days of culture they reported similar values of proteoglycan synthesis, and collagen $\mathrm{I}$ and $\mathrm{X}$ expression, as compared to traditional pellet cultures. While these results were encouraging, the scaffold fabrication method led to constructs with Young's modulus on the order of $22 \mathrm{kPa}$, much lower than that of articular cartilage [46]. Only recently water based polyurethane particles have been applied in additive manufacturing in combination with polyethylene glycol (PEO, viscosity enhancer) $[48,49]$. PEU particles combined with PEO, hyaluronan and transforming growth factor- $\beta 3$ (TGF- $\beta 3$ ) were extruded from water solutions into scaffolds that showed great potential for the chondrogenic differentiation of hMSCs. The authors also showed the high resilience of the scaffolds thus prepared, although a relatively low storage modulus of $200-500 \mathrm{kPa}$ was measured [48]. To tackle these issues and create a platform that has sufficient compressive mechanical properties and an extended elastic regime while providing an adequate $3 \mathrm{D}$ environment for cells, we have optimized the additive manufacturing process of an elastic PEU. Here we report 3D fiber-deposited elastic PEU scaffolds that support the re-differentiation of a de-differentiated chondrogenic cell line (ATDC5) and promote the deposition of an ECM characteristic of hyaline cartilage, thus resulting on ideal candidates for their use in MACI interventions. The scaffolds were fabricated with a variety of pore shapes and architectures resulting in the capability of fine-tuning the mechanical properties of the overall tissue-scaffold construct.

\section{Materials and methods}

\subsection{Materials}

The poly(ester)urethane (PEU) was kindly provided by Polyganics B.V (Groningen, The Netherlands) and kept under vacuum at $-20^{\circ} \mathrm{C}$ to avoid degradation. The PEU was synthesized from a random polyester prepolymer soft segment containing $50 \mathrm{~mol} \%$ DL-Lactide $(50 / 50 \mathrm{D} / \mathrm{L}$ ratio) and $50 \mathrm{~mol} \% \epsilon$-Caprolactone. This prepolymer $(\mathrm{Mn}=2000 \mathrm{~g} / \mathrm{mol})$ was synthesized via ring opening polymerization using butanediol as an initiator. The soft segment prepolymer was chain extended with a uniform 5-block urethane hard segment (BDI-BDO-BDI-BDO-BDI). The resulting polyurethane consists of $23 \mathrm{wt} \%$ of amorphous soft segment and $77 \mathrm{wt} \%$ hard segment. The synthesis of the copolymer has been reported elsewhere [50]. 


\subsection{Additive manufacturing}

Scaffolds were deposited with a Bioscaffolder system (SYSENG) equipped with a temperature controller and a G22 needle $(400 \mu \mathrm{m}$ internal diameter) and with a pore size and shape (angle of deposition) of $500 \mu \mathrm{m}$ and $90^{\circ}, 60^{\circ}, 45^{\circ}$ or $30^{\circ}$ and with a $200 \mu \mathrm{m}$ pore size and $90^{\circ}$ angle. PEU was deposited at a feed (travel) rate of $350 \mathrm{~mm} / \mathrm{R}$, a dispensing speed of $30 \mathrm{RPM}$, dispensing pressure of $0.8 \mathrm{MPa}$ and with a layer thickness of $0.3 \mathrm{~mm}$. The optimal printing temperature was found to be $175^{\circ} \mathrm{C}$.

The printing quality was assessed by means of reproducibility (error) of the process following the equation:

$\varepsilon=\frac{d_{\text {fiber }}-d_{\text {needle }}}{d_{\text {fiber }}}$

were, $\mathrm{d}$ is diameter. The diameter was calculated from optical microscopy images (Fig. S1).

\subsection{Gel permeation chromatography (GPC)}

The molecular weight ( $\mathrm{Mn}, \mathrm{Mw}$ and polydispersity index, PI) of the materials before and after printing was evaluated with a Prominence-i GPC system equipped with photodiode array and refractive index detectors. For all the measurements $50 \mu \mathrm{L}$ of a $2 \mathrm{mg} \mathrm{mL}^{-1}$ polymer solution in dimethyl formamide were analyzed. The GPC column was calibrated with a polystyrene standard up to $200.000 \mathrm{~g} \mathrm{~mol}^{-1}$.

\subsection{Scanning electron microscopy (SEM)}

The structure and morphology of the additive manufactured scaffolds were analyzed by scanning electron microscopy. Prior to imaging, samples were coated with a nanometric layer of gold via sputtering on a Cressington Sputter coater 108 Auto and visualized under a FEI/Philips XL-30 microscope on secondary electrons mode at a typical acceleration voltage of $10 \mathrm{keV}$.

\subsection{Micro computed tomography $(\mu \mathrm{CT})$}

$\mu \mathrm{CT}$ scans were recorded using a Bruker Skyscan $127211 \mathrm{Mp}$ scanner with cone beam geometry and a $4032 \times 2688$ detector. The scanner is air damped reducing vibration disturbances. Alignment, thermal drift of the cathode spot, beam hardening, and ring artefacts are corrected using the software suite supplied by Bruker. The isotropic voxel size was $3^{3} \mu \mathrm{m}^{3}$. The 3D datasets were reconstructed using FDK implemented in NRecon 1.7.1.0 (Bruker microCT) [51] and analyzed with the software CTAn (Bruker). A VOI (object volume) corresponding as close as possible to the whole scaffold was selected, in order to balance potential morphology inhomogeneities due to printing. The VOI selection was refined to take into account the periodical scaffold morphology resulting from the specific deposition pattern used. In particular, it was constructed so as to include an integer amount of repeating cells. Open and closed porosity values were then calculated via the 3D analysis function available in the software.

\subsection{Cell culture}

ATDC5, a teratocarcinoma derived chondrogenic cell line, was used for this study. Cells were cultured at a $10.000 \mathrm{cell} \cdot \mathrm{cm}^{-2}$ density in DMEM:F-12 media supplemented with $5 \%$ fetal bovine serum (FBS) and 1\%Pen/Strep (penicillin streptavidin). Cells were subculture at $80 \%$ confluence.

\subsection{Cell culture in 3D scaffolds and chondrogenic differentiation}

Samples of 3D PEU scaffolds were cut using a biopsy puncher to obtain cylindrical samples of $4 \mathrm{~mm}$ diameter and $4 \mathrm{~mm}$ height. Samples were placed on a 24 -well plate and sterilized by immersing them $15 \mathrm{~min}$ in a $70 \%$ ethanol solution after which samples were washed thoroughly with phosphate buffer saline (PBS) (Gibco) three times. In order to promote a higher cell attachment, samples were coated with truncated recombinant human vitronectin (ThermoFisher), commonly used as coating for cell culture of pluripotent stem cells, at a concentration $0.5 \mu \mathrm{g} / \mathrm{cm}^{2}$, assuming a surface area per scaffold of $16 \mathrm{~mm}^{2}$. In brief, a vitronectin stock solution was diluted in PBS to reach the desired final concentration. 3 scaffolds were placed in an Eppendorf tube, covered with $500 \mu \mathrm{L}$ of vitronectin solution and left at room temperature for $1 \mathrm{~h}$. Afterwards, samples were placed on a 24 well-plate and $2 \cdot 10^{5}$ cells per scaffold $\left(8 \cdot 10^{6} \mathrm{cell} / \mathrm{cm}^{3}\right)$ were seeded at a concentration of $8 \cdot 10^{6} \mathrm{cell} / \mathrm{mL}$ (that is $25 \mu \mathrm{L}$ of cell dispersion per scaffold) without previous scaffold rinsing. Cells were left to attach to the scaffolds for $2 \mathrm{~h}$ in the incubator $\left(37^{\circ} \mathrm{C}, 5 \% \mathrm{CO}_{2}\right)$. Thereafter, the scaffolds were flipped and left to incubate for another $2 \mathrm{~h}$. After $4 \mathrm{~h}$ of cell seeding, $2 \mathrm{~mL}$ of DMEM-F-12 supplemented with penicillin (100 units $/ \mathrm{mL})$ and streptomycin $(100 \mathrm{lg} / \mathrm{mL})$ were added. After $24 \mathrm{~h}$ of culture, the samples were placed in new 24-well plates to avoid cross-talk with cells attached on the bottom of the plate and media was changed to differentiation media on the samples used for this purpose. Differentiation media consisted of DMEM:F-12 supplemented with $100 \mathrm{U} / \mathrm{mL}$ Penicillin-Streptomycin, $100 \mu \mathrm{g} / \mathrm{ml}$ ITS (insulin, transferrin, selenium) premix, $0.2 \mathrm{mM}$ L-Ascorbic acid 2-phosphate and 5\% FBS. Scaffolds were harvested at day 14 and 28 for DNA assays, glycosaminoglycan (GAG), immunofluorescence, polymerase chain reaction (PCR) and mechanical analysis.

\subsection{Cell pellet culture}

To form pellets, $0.25 \cdot 10^{6}$ cells were placed in a $15 \mathrm{~mL}$ polypropylene tube with $500 \mu \mathrm{L}$ maintenance media and centrifuged at $500 \mathrm{rcf}$ for $5 \mathrm{~min}$ to form a flat pellet at the bottom of the tube. The tubes were left on the incubator for $24 \mathrm{~h}$ after which rounded pellets were spontaneously formed. $24 \mathrm{~h}$ after seeding, media was replaced to differentiation or maintained in basal media conditions (control pellets). Media change was performed every second day, as for cells cultured in the scaffolds.

\subsection{DNA and glycosaminoglycan (GAG) quantification}

For DNA assays, samples were harvested, placed in Eppendorf tubes, and frozen at $-80^{\circ} \mathrm{C}$ until further analysis. To facilitate digestion of the ECM and cell lysis, the scaffolds were freeze-thawed 3 times in liquid $\mathrm{N}_{2}$. The ECM was digested by a Proteinase $\mathrm{K}$ treatment. In brief, samples placed in a $1.5 \mathrm{~mL}$ Eppendorf tubes were incubated $16 \mathrm{~h}$ at $56^{\circ} \mathrm{C}$ with $250 \mu \mathrm{L}$ of $50 \mathrm{mM}$ Tris $/ 1 \mathrm{mM}$ EDTA $/ 1 \mathrm{mM}$ iodoacetamide solution containing $1 \mathrm{mg} / \mathrm{mL}$ Proteinase K. After digestion, the samples were freeze-thawed 3 times in liquid $\mathrm{N}_{2}$ to facilitate the DNA extraction. DNA was measured with a CyQuant cell proliferation assay (Thermofisher). In brief, cellular RNA was degraded by incubating the samples for $1 \mathrm{~h}$ at RT with lysis buffer containing RNase A. $100 \mu \mathrm{L}$ of each sample (triplicates) were placed in a 96-well plate and $100 \mu \mathrm{L}$ of $2 x$ GR-dye solution were added and left to incubate for $15 \mathrm{~min}$ at RT. A standard curve was prepared with a DNA standard solution and fluorescence intensity was measured at $520 \mathrm{~nm}$. Samples from Proteinase K digestion step were used to measure GAG content using a DMMB solution (16 mg DMMB in $5 \mathrm{ml}$ ethanol). In brief, $150 \mu \mathrm{L}$ of DMMB solution were mixed with $25 \mu \mathrm{L}$ of sample and $5 \mu \mathrm{L}$ of $2.3 \mathrm{M} \mathrm{NaCl}$ were mixed on a black well plate and the absorbance difference at 
525 and $595 \mathrm{~nm}$ was measured. Data was compared to a standard curve.

\subsection{Histology}

Samples for histological analysis were fixed for $30 \mathrm{~min}$ in $4 \%$ paraformaldehyde and then rinsed 3 times in PBS. After fixation, samples were cut opened along the long axis. Samples stained for GAGs were first stained 10 min in Weigert's iron hematoxylin solution to counterstain the cell nucleus black and washed thoroughly in running tap water. Thereafter, samples were stained $5 \mathrm{~min}$ in a $0.1 \%$ solution of Safranin-O and then rinsed with PBS until the solution was clear. Pricosirius Red stain was done following manufacturer's instructions. In brief, samples were incubated for $2 \mathrm{~h}$ in Pricosirius Red solution and then rinsed quickly in $0.5 \%$ acetic acid solution. Afterwards, samples were rinsed in PBS 3 times.

\subsection{Immunofluorescence}

Samples were cut opened in half with a scalpel and prepared by fixing them $30 \mathrm{~min}$ in $4 \%$ paraformaldehyde, followed by rinsing in PBS and permeabilization $15 \mathrm{~min}$ in a $0.1 \%$ Triton X-100 solution in PBS. Blocking was done for $1 \mathrm{~h}$ in a solution of $3 \%$ BSA (Bovine Serum Albumin) in PBS. After rinsing the blocking solution, samples were incubated $1 \mathrm{~h}$ at room temperature with mouse anticollagen I (1:500), rabbit anti-collagen II (1:400) antibodies and AlexaFluor 488 Phalloidin. After $1 \mathrm{~h}$ the solution was removed and the samples were rinsed 3 times with 0.3\% BSA and 0.01\% Triton X-100 in PBS. Secondary antibodies anti-rabbit AlexaFluor 647 and anti-mouse AlexaFluor 568 were incubated in the dark for $30 \mathrm{~min}$ at room temperature in PBS (1:200), followed by rinsing with PBS and staining with Hoechst 33,342 (1:3000) in PBS for 10 min. After final rinsing with PBS samples were observed under a Leica TCS SP8 CARS confocal microscope.

\subsection{Gene expression analysis}

Total RNA was extracted with RNeasy Mini kit with on column DNase treatment (Qiagen) according to the manufacturer's protocol. cDNA was synthesized from 200 ng total RNA, using iScript cDNA synthesis kit (Bio-Rad) on a $20 \mu \mathrm{L}$ reaction following manufacturer's instructions. RT-PCRs were prepared on a total volume of $10 \mu \mathrm{L}$ with iQ SYBR green Supermix (Bio-Rad), $0.2 \mu \mathrm{M}$ forward and reverse primers (see Table 1 ) and 3 ng cDNA and DEPC treated water. For no-RT controls, an equivalent volume of DNase and RNasefree water was used. A CFX96 ${ }^{\mathrm{TM}}$ IVD Real-Time PCR system (BioRad) was used with a thermal cycle of $50{ }^{\circ} \mathrm{C}$ for $2 \mathrm{~min}, 95{ }^{\circ} \mathrm{C}$ for $2 \mathrm{~min}$, and then $95{ }^{\circ} \mathrm{C}$ for $15 \mathrm{~s}$ and $60{ }^{\circ} \mathrm{C}$ for $30 \mathrm{~s}$ for a total of 40 cycles. Ct values of RT-PCR were normalized against the housekeeping gene and analysed using the $\Delta \Delta \mathrm{Ct}$ model.

\subsection{Mechanical testing}

Bare scaffolds and cell-scaffolds constructs that were punched from $20 \times 20 \mathrm{~mm}^{2}$ blocks to a $4 \mathrm{~mm}$ diameter and $4 \mathrm{~mm}$ height cylinders. The actual dimensions were measured with a caliper and

Table 1

List of primers used for RT-PCR experiments.

\begin{tabular}{lll}
\hline Gene & Forward primer $5^{\prime}$ to $3^{\prime}$ & Reverse primer $5^{\prime}$ to $3^{\prime}$ \\
\hline Sox9 & AGTACCCGCATCTGCACAAC & ACGAAGGGTCTCTTCTCGCT \\
Col1a1 & GCTCCTCTTAGGGGCCACT & CCACGTCTCACCATTGGGG \\
Col2a1 & AGTACCTTGAGACAGCACGAC & GCTCTCAATCTGGTTGTTCAG \\
Col Xa1 & TTCTGCTGCTAATGTTCTTGACC & GGGATGAAGTATTGTGTCTTGGG \\
RunX2 & GGAACCAAGAAGGCACAGAC & CGGGACACCTACTCTCATAC \\
\hline
\end{tabular}

noted down for data analysis. The compressive mechanical properties were measured in the dry state in unconfined and nonequilibrium conditions. Samples for biological studies were measured in PBS before and after cell culture. A TA ElectroForce (TA Instruments) mechanical tester equipped with a $45 \mathrm{~N}$ load cell was used for all the measurements. The instrument was controlled with WinTest7 software. Tests were conducted at a strain rate of $0.01 \mathrm{~mm} / \mathrm{s}$. The experiments were run until approximately $50 \%$ deformation (or until the maximum applicable load was reached). No pre-load was applied and the initial recorded data corresponding to the compression plate traveling to contact the sample was subtracted prior data analysis. The Young's modulus was calculated from the slope of the engineering strain-stress curve between $0.2 \%$ and $1.2 \%$ strain. This range was chosen to avoid barreling of the sample and correction for the dimensions of the sample.

\subsection{Statistical analysis}

Statistical significance was calculated for Young's modulus measurements, DNA assay, GAG assay and PCR analysis by two-way ANOVA with Tukey's multiple comparison test; $\left({ }^{* * *}\right) p<0.0001$, $\left({ }^{* *}\right) p<0.001,\left({ }^{* *}\right) p<0.01$ and $\left(^{*}\right) p<0.1$.

\section{Results}

\subsection{Additive manufacturing of poly(ester)urethane (PEU)}

A biodegradable PEU was used to prepare additive manufactured scaffolds of different pore sizes and structures. PEU had a high molecular weight of approximately $125.000 \mathrm{~kg} / \mathrm{mol}$ (Fig. 1a and b), as compared to traditional polyesters used for additive manufacturing. Increasing molecular weight of polymers generally results on a higher viscosity that, together with the thermal degradation potential (on the presence of small amounts of water) of polyesters limit their exploitation in additive manufacturing applications [52]. After careful optimization of fabrication parameters such as temperature, feed speed and printer-head travel speed, PEU scaffolds were fabricated with an initial degradation step that enabled their extrusion through the printer needle. Changes in the weight average molecular weight $(\mathrm{Mw})$, number average molecular weight $(\mathrm{Mn})$ and polydispersity $(\mathrm{Mw} / \mathrm{Mn})$ of the polymer were monitored after 1 and $2 \mathrm{~h}$ of continuous deposition (Fig. 1a and b), showing an initial decrease of $\mathrm{Mw}$ from $125.000 \mathrm{~kg} / \mathrm{mol}$ to $80.000 \mathrm{~kg} / \mathrm{mol}$, approximately, which remained constant during the manufacturing process. The decrease in the molecular weight is moreover largely ascribed to degradation of the largest polymer chains, resulting on a decrease of the polydispersity from 3.1 to $\approx 2.6-2.8$. The printing quality was assessed by means of reproducibility (error) resulting on an error of $4 \pm 1 \%$ with an average fiber diameter of $418 \pm 5 \mu \mathrm{m}$, as compared to the theoretical $400 \mu \mathrm{m}$ of the needle (Supplementary Fig. S1).

\subsection{Scaffold architecture vs mechanical properties}

FDM is a versatile technique that allows for the fabrication of scaffolds with a great variety of pore sizes and geometries that in turn results on products with different mechanical properties (Fig. 1c). In order to investigate the range of mechanical properties achievable with the biodegradable PEU on the shape of additive manufactured scaffolds, different pore sizes and pore shapes were designed and fabricated. Scaffolds with theoretical pore sizes and printing angles of $200 \mu \mathrm{m}$ and $90^{\circ}, 400 \mu \mathrm{m}$ and $90^{\circ}, 600 \mu \mathrm{m}$ and $90^{\circ}, 800 \mu \mathrm{m}$ and $90^{\circ}, 800 \mu \mathrm{m}$ and $60^{\circ}$ and $800 \mu \mathrm{m}$ and $45^{\circ}$ were fabricated and their mechanical properties were measured under compression. Stress-strain curves of the fabricated scaffolds showed the characteristic poroelastic behaviour when the deposition pattern followed a $90^{\circ}$ or $60^{\circ}$ angle (Fig. 1e,f). After an initial 


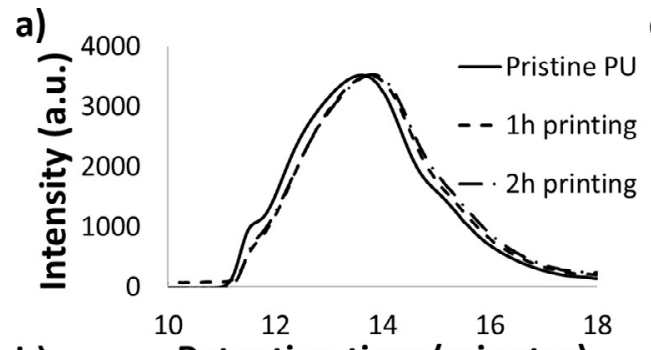

\begin{tabular}{cccc} 
b) & \multicolumn{4}{c}{ Retention time (minutes) } \\
\cline { 2 - 4 } Sample & $\begin{array}{c}\mathrm{Mn} \\
\left(\mathrm{kg} \cdot \mathrm{mol}^{-1}\right)\end{array}$ & $\begin{array}{c}\mathrm{Mw} \\
\left(\mathrm{kg} \cdot \mathbf{m o l}^{-1}\right)\end{array}$ & $\mathrm{Mw} / \mathrm{Mn}$ \\
\hline Pristine & 40152 & 125771 & 3.1 \\
\hline 1h printing & 30188 & 80295 & 2.6 \\
\hline 2h printing & 29938 & 84220 & 2.8 \\
\hline
\end{tabular}

d)

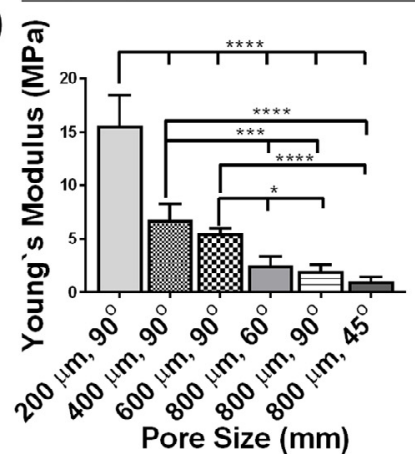

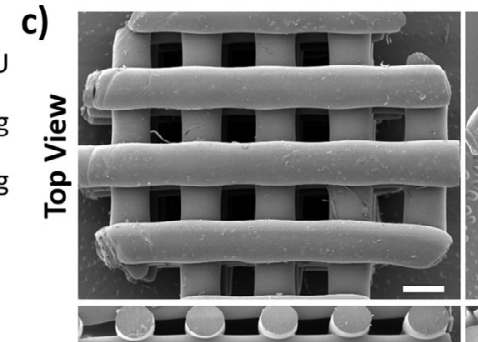

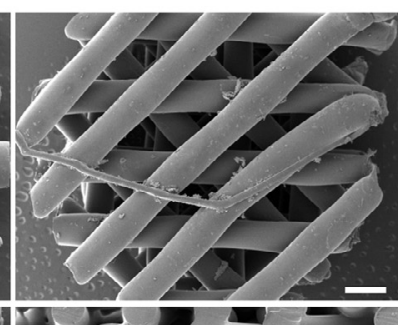

e)

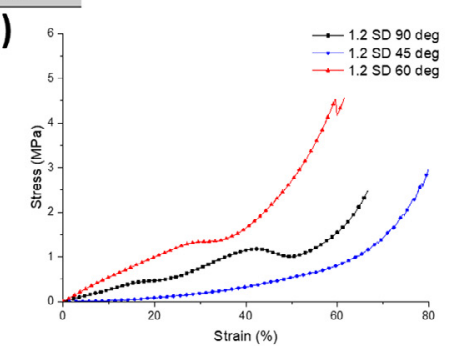

f)
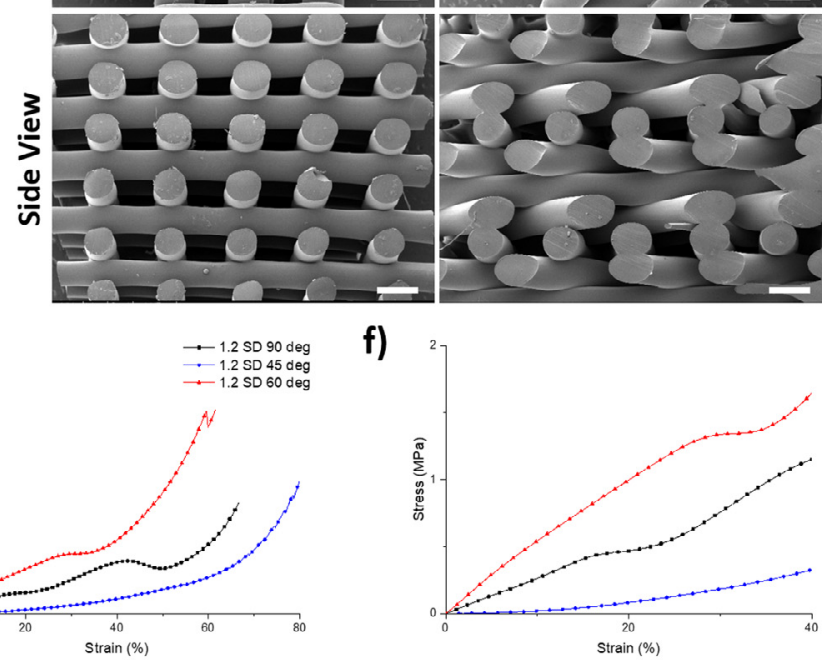

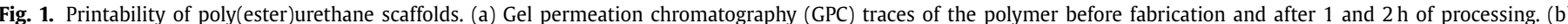

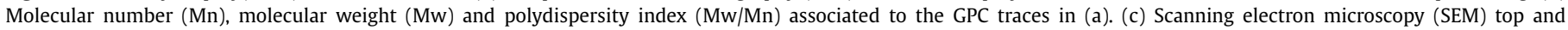

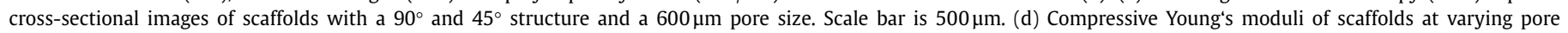

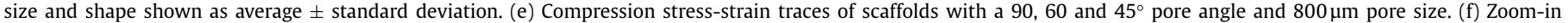
of the elastic regime.

elastic regime, the scaffold pores started to collapse resulting on an extended plateau or a reduced inflexion point on the stressstrain traces, followed by an increased stress resulting from the sample densification. Structures deposited with a $45^{\circ}$ pattern, presented only an initial elastic regime followed by a sharp stress increase, resulting from the densification of the material. These scaffolds also presented the lowest Young's modulus, with values in compression of $1.0 \pm 0.4 \mathrm{MPa}$, as compared to their counterparts with the same pore size of $800 \mu \mathrm{m}$ but pore shapes of $60^{\circ}$ and $90^{\circ}$ that presented Young's moduli $(E \pm \mathrm{SD})$ of $2.5 \pm 0.9 \mathrm{MPa}$ and $2.0 \pm 0.6 \mathrm{MPa}$, respectively. A decrease of the pore size of 200,400 and $600 \mu \mathrm{m}$ (from the initial $800 \mu \mathrm{m}$ pore size scaffolds), to generate scaffolds with a pore size of 600,400 and $200 \mu \mathrm{m}$ respectively, resulted in a non-linear increase of the mechanical properties under compression. Thus, scaffolds (all with a $90^{\circ}$ pattern) with varying pore size of 600,400 and $200 \mu \mathrm{m}$ showed Young's moduli of $5.6 \pm 0.5,7 \pm 1$ and $16 \pm 3 \mathrm{MPa}$, respectively. A deeper analysis of stress-strain traces collected under compression showed that the elastic limit or yield strain of the scaffolds was dependent on the printing pattern. Scaffolds structures with a $90^{\circ}$ pattern present the lowest elastic limit that was as high as approximately $20 \%$ strain, followed by scaffolds with a $60^{\circ}$ pattern and $30 \%$ elastic limit. The elastic limit of scaffolds with a $45^{\circ}$ pattern presented an elastic limit over $50 \%$ strain.

\subsection{Fabrication and characterization of scaffolds for in-vitro tissue engineering}

Next, we fabricated scaffolds aimed to promote the formation of cartilaginous tissue. We choose scaffold architectures with pore sizes of 200 and $500 \mu \mathrm{m}$ with deposition patterns of $30^{\circ}, 60^{\circ}$ and $90^{\circ}$ We choose these pore sizes under the hypothesis that the materials would undergo certain degradation before a complete neotissue is formed. Thus, choosing mechanical properties that are well above those of native articular cartilage (Aggregate modulus of $0.08-2 \mathrm{MPa}[53,54]$ and Young's modulus of $0.3-0.8 \mathrm{MPa}$ for strain-relaxation experiments $[53,55])$. The $E$ under compression of samples submerged in a PBS bath showed values that are well in agreement with those calculated on the dry state (Fig. 2b). Thus, scaffolds with $500 \mu \mathrm{m}$ pore size and $90^{\circ}, 60^{\circ}$ and $30^{\circ}$ patterns had $\mathrm{E}$ of $6 \pm 1,2.5 \pm 0.4$ and $2.6 \pm 0.1 \mathrm{MPa}$, respectively. Scaffolds with a $200 \mu \mathrm{m}$ pore size and $90^{\circ}$ pattern showed an $\mathrm{E}$ of $11.4 \pm 0.5 \mathrm{MPa}$.

The structure of the scaffolds was characterized by SEM, showing again high fidelity between the designed and produced patterns (Fig. 2a). $\mu \mathrm{CT}$ scans revealed a porosity of $47.8 \%, 39.8 \%, 46.2 \%$ and $18.9 \%$ for scaffolds with $500 \mu \mathrm{m}$ pore size and $90^{\circ}, 60^{\circ}$ and $30^{\circ}$ patterns and with a $200 \mu \mathrm{m}$ pore size and $90^{\circ}$ pattern, respectively (Table 2). As expected, the variation between fiber deposition patterns for a given pore size $(500 \mu \mathrm{m})$ results in only small differences in porosity, closed porosity, total surface area and total pore volume. Only patterns of $60^{\circ}$ seem to have a decrease in porosity and pore volume. These also presented the highest connectivity (Euler number), while scaffolds with $500 \mu \mathrm{m}$ pore size and $30^{\circ}$ printing pattern displayed the lowest connectivity (or highest tortuosity). However, a decrease in the pore size (500 vs $200 \mu \mathrm{m}$ ) results on an important decrease in porosity and total pore volume of approximately 2.5 -fold, which is proportional to the decrease in pore size. The small percentage of closed porosity in all samples (defined as a connected assemblage of space (black) voxels that is 
a)
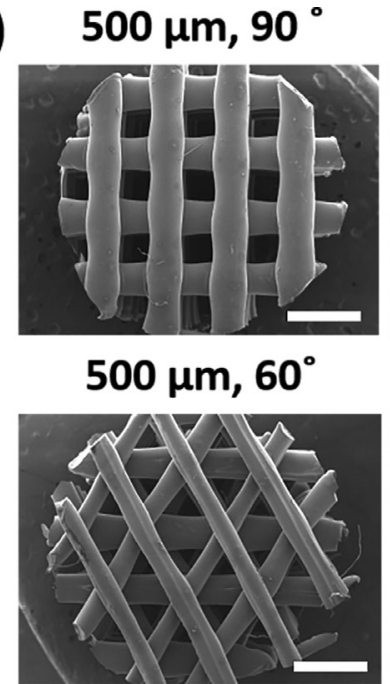

$200 \mu \mathrm{m}, 90^{\circ}$

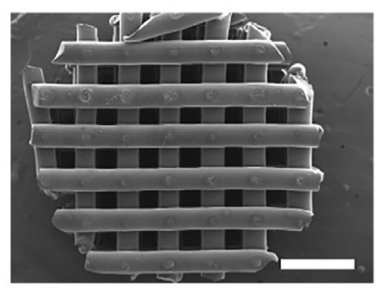

$500 \mu \mathrm{m}, 30^{\circ}$

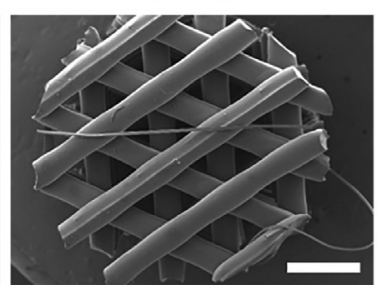

b)

Before culture

Differentiation $14 d$

$\widehat{\sigma}$ Differentiation 28d

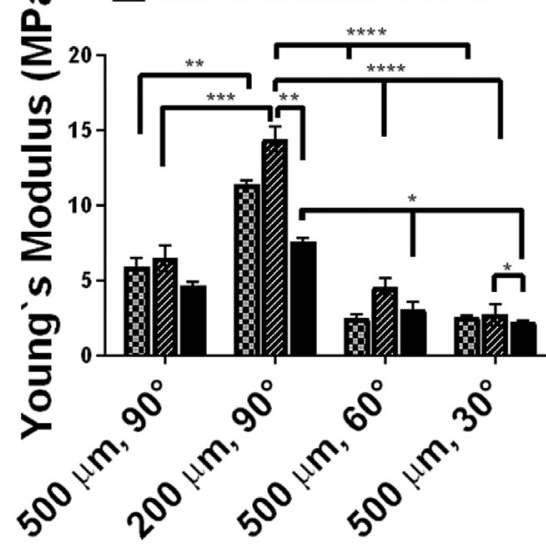

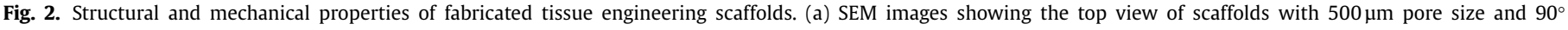

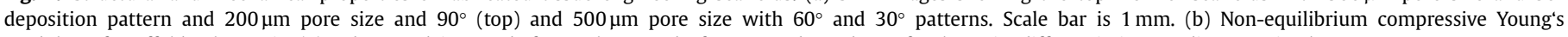

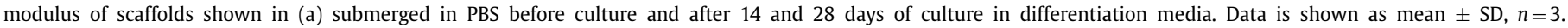
Statistical significance is calculated by two-way ANOVA; $\left({ }^{* * *}\right) p<0.0001,\left({ }^{* * *}\right) p<0.001,\left({ }^{* *}\right) p<0.01$ and $\left({ }^{*}\right) p<0.1$.

Table 2

Porosity, closed porosity, surface area, total available pore volume and connectivity of fabricated scaffolds with a given dimension of $4 \mathrm{~mm}$ diameter and $4 \mathrm{~mm}$ height (total volume of $50.2 \mathrm{~mm}^{3}$ ).

\begin{tabular}{lllllr}
\hline $\begin{array}{l}\text { Scaffold pore size } \\
\text { and pattern angle }\end{array}$ & Porosity (\%) & $\begin{array}{l}\text { Closed porosity } \\
(\%)\end{array}$ & $\begin{array}{l}\text { Total surface } \\
\text { area }\left(\mathrm{mm}^{2}\right)\end{array}$ & $\begin{array}{l}\text { Total pore } \\
\text { volume }\left(\mathrm{mm}^{3}\right)\end{array}$ & $\begin{array}{l}\text { Connectivity } \\
(\text { Euler Number) }\end{array}$ \\
\hline $500 \mu \mathrm{m}, 90^{\circ}$ & 47.8 & 0.038 & 271.3 & 24.0 & -315 \\
$500 \mu \mathrm{m}, 60^{\circ}$ & 39.8 & 0.099 & 263.1 & 19.9 & -154 \\
$500 \mu \mathrm{m}, 30^{\circ}$ & 46.2 & 0.031 & 266.3 & 23.2 & -358 \\
$200 \mu \mathrm{m}, 90^{\circ}$ & 18.9 & 0.092 & 238.0 & 9.5 & -367 \\
\hline
\end{tabular}

fully surrounded on all sides in 3D by solid (white) voxels), can probably be ascribed to trapped air bubbles within the material.

\subsection{In-vitro cartilage formation}

ATDC5 cells were cultured on the additive manufactured scaffolds with different pore architectures and sizes for 2 and 4 weeks in chondrogenic and basal media and the deposited tissue was analysed by histology and immunofluorescence. Cell proliferation, glycosaminoglycan deposition and phenotypic state of cells were also studied. As comparison, ATDC5 cells were also analysed after pellet culture, the gold-standard for in-vitro chondrognesis.

\subsubsection{Cell proliferation and deposition of a specialized extra cellular matrix (ECM)}

Histological observation of the cell/scaffold constructs was done via staining with Safranin-O, specific for glycosaminoglycans (Fig. 3a), and Picosirius Red, specific for collagens (Fig. S2). After 14 and 28 days of culture a large amount of cells were visualized growing on the outer perimeter of the scaffolds in all scaffold architectures (Fig. 3a, top view and Fig. S2). However, a large amount of cells were also observed growing inside the scaffold material after 14 days of culture. A detailed observation of the samples revealed a larger amount of cells growing inside the scaffolds after 28 days of culture in differentiation conditions as compared to basal media and 14 days of culture (in both media conditions). Contrary to this trend, samples with pore size of $200 \mu \mathrm{m}$ showed a reduced cell number with extended culture time. We hypothesize that the reduced pore size and the large amount of cells growing on the outer perimeter of the scaffold restricted or limited the oxygen and nutrient transport through these pore sizes. Samples with a $500 \mu \mathrm{m}$ pore size and $90^{\circ}$ angle showed the highest cell number within the scaffolds, which became specially pronounced after 28 days of culture. Scaffolds with a pore shape of $60^{\circ}$ showed a higher cell population than their counterparts at $30^{\circ}$ (Fig. $3 \mathrm{a}$ ). An increased cell number was confirmed by quantification of DNA content on the scaffolds after 14 and 28 days of culture in both media conditions (Fig. 3b). After only 14 days of culture cell number increased to more than double (as compared to initial seeding of $2 \cdot 10^{5}$ cells) in all scaffold architectures and culture conditions. After 28 days, values of over $2 \cdot 10^{6}$ cells were measured, indicating a continuous cell proliferation. As observed by histology, samples with a reduced pore shape of $200 \mu \mathrm{m}$ presented a lower cell number after 28 days in both differentiation and basal media with significant differences in differentiation media. A total cell number in differentiation condition of $2.1 \cdot 10^{6} \pm 1.4 \cdot 10^{5}$ was quantified versus the $2.5 \cdot 10^{6} \pm 0.40 \cdot 10^{5}, 2.4 \cdot 10^{6} \pm 1.3 \cdot 10^{5}$ and $2.5 \cdot 10^{6} \pm 1.1 \cdot 10^{5}$ measured for the $500 \mu \mathrm{m} 90^{\circ}, 60^{\circ}$ and $30^{\circ}$, respectively. Control pellets showed the same trend, with an initial cell doubling in the differentiation condition and a rather senescent behavior on the consecutive 2 weeks (Fig. S3). However, when normalizing the calculated cell numbers to the actual free pore volume of each of the scaffolds (as measured by $\mu \mathrm{CT}$ ), we observed a totally different trend (Fig. S8, a). Scaffolds with a $200 \mu \mathrm{m}$ pore size present a cell number per $\mathrm{mm}^{3}$ of $2.3 \cdot 10^{5}$ after 28 days in differentiation media as compared to scaffolds with $500 \mu \mathrm{m}$ pore size that present a much lower cell density of $1 \cdot 10^{5}$ for $90^{\circ}$ and $30^{\circ}$ patterns and of $1.2 \cdot 10^{5}$ for scaffolds with a $60^{\circ}$ pattern. These cell densities were also significantly different after only 14 days of culture and in both media conditions.

Articular cartilage has a characteristic ECM composition that is rich in GAGs and Collagen II. Thus, it is important to verify that the composition of the engineered neo-tissue resembles that one of the native one. Optical observation of the stained samples showed 
a) 14 days 28 days
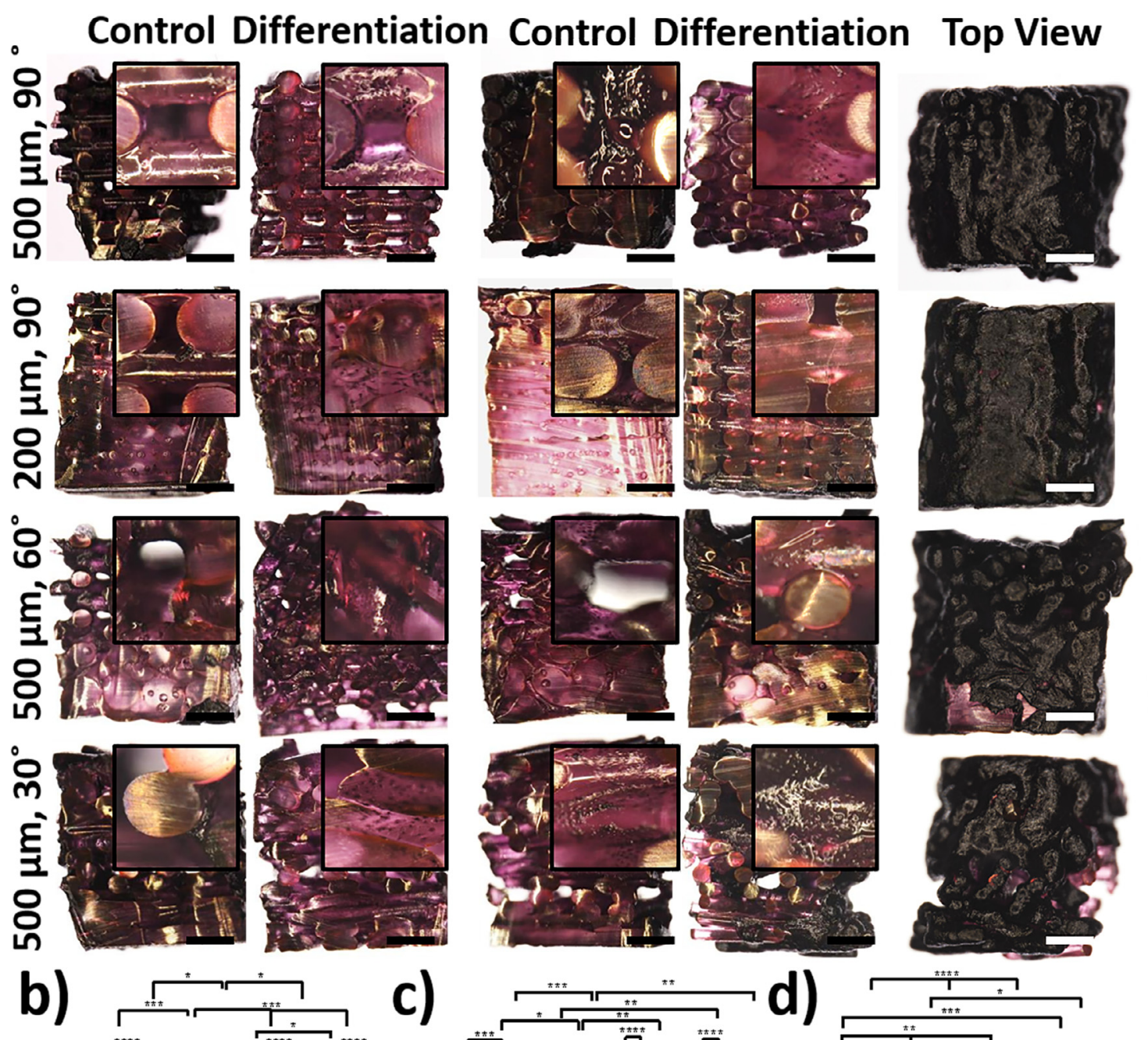

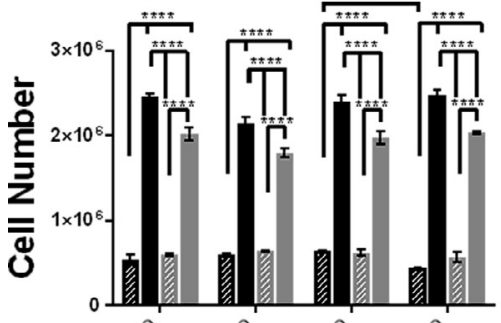

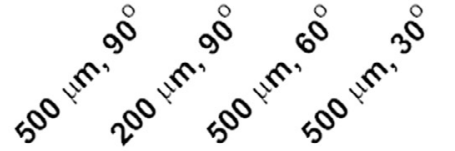
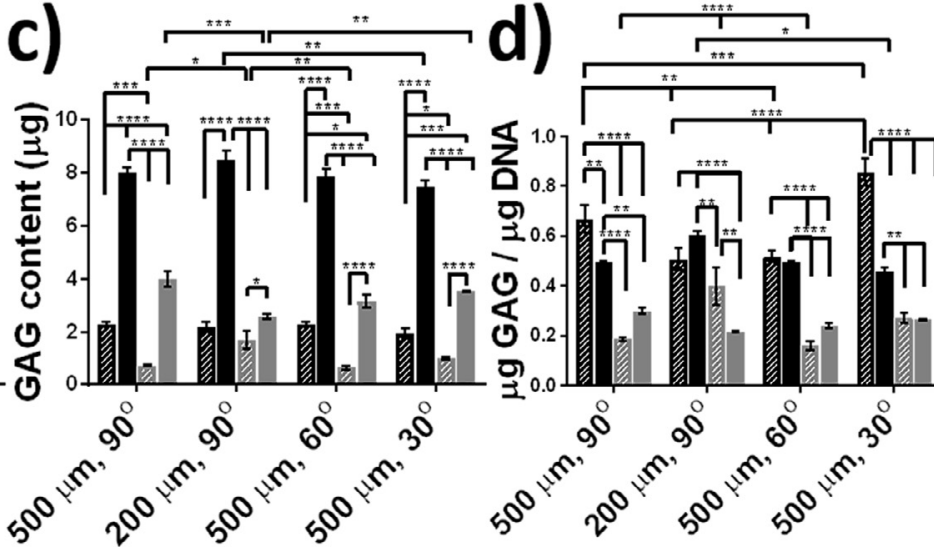

Differentiation 14d

Differentiation 28d

Maintenance 14d

Maintenance 28d

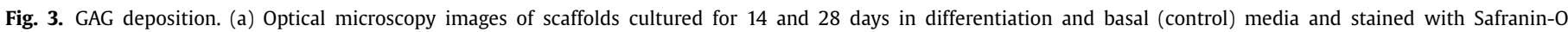

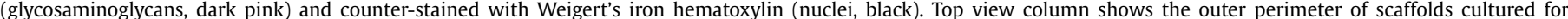

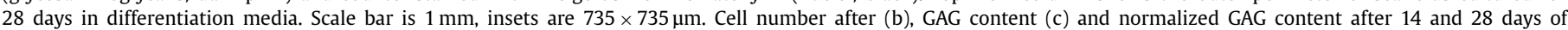

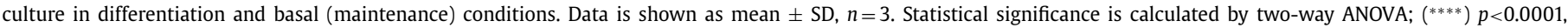
$\left({ }^{* * *}\right) p<0.001,\left({ }^{* *}\right) p<0.01$ and $\left({ }^{*}\right) \mathrm{p}<0.1$.

an overall increase of GAG deposition from day 14 to day 28 of culture in differentiation as well as basal media (Figs. 3a). GAG deposition was observed as a dark pink stain (in contrast to the unspecific pale pink stain of the scaffolds) that became more intense over time when comparing samples cultured for 14 and 28 days and for samples cultured in differentiation media. Similarly to what was observed in terms of cell number, $200 \mu \mathrm{m}$ pore size scaffolds appeared to have very little amount of deposited GAGs, with high depositions peaking in scaffolds wit $500 \mu \mathrm{m}$ and $90^{\circ}$ and $60^{\circ}$ patterns.

The deposition of GAGs was also analyzed quantitatively by DMMB assay (Fig. $3 c$ and d) for all scaffolds on the different 
structural designs. As observed via histological staining, the amount of deposited GAGs was for all the cases higher in differentiation conditions than in control conditions and after 28 days. After 14 days of culture, samples in differentiation media deposited around $0.5 \mu \mathrm{g}$ GAG per $\mu \mathrm{g}$ DNA (a total of $\sim 2 \mu \mathrm{g}$ GAG per scaffold) with no significant difference between different structures as compared to the $0.3 \mu \mathrm{g}$ per $\mu \mathrm{g}$ DNA measured for control samples (a total of $\sim 1 \mu \mathrm{g}$ GAG). After 28 days of culture the deposition of GAGs in differentiation conditions increased, reaching values of $\sim 8 \mu \mathrm{g}$ per scaffold but keeping constant the amount of GAG deposited per cell (0.5-0.6 $\mu$ g GAG per $\mu$ g DNA) (Fig. 3c and d). Similarly, control samples maintained the amount of GAG deposited per cell with total GAGs values of $2.5-4 \mu \mathrm{g}$ with no significant differences between architectures. Pellet cultures showed after 28 days of culture higher values of GAG deposition per cell in both differentiation and basal conditions ( $\sim 0.7$ and $1.5 \mu \mathrm{g}$ GAG per $\mu \mathrm{g}$ DNA, respectively) (Fig. S4). Similarly to the cell number, the GAG content and GAG / DNA was also normalized to the free pore volume calculated from $\mu \mathrm{CT}$ data (Fig. S8, b and c). The calculated GAG density was also significantly higher on scaffolds with the lowest pore size, e.g. $200 \mu \mathrm{m}$, with $0.9 \mu \mathrm{g} / \mathrm{mm}^{3}$ as compared to the 0.3 , 0.3 and $0.4 \mu \mathrm{g} / \mathrm{mm}^{3}$ of scaffolds with $500 \mu \mathrm{m}$ pore size and $90^{\circ}$, $30^{\circ}$ and $60^{\circ}$ patterns after 14 and 28 days of culture in differentiation media.

The specialized matrix of cartilage accounts for a high percentage of Collagen II. Evaluation of the total collagen being deposited on the printed scaffolds was performed qualitatively via histology and microscopic evaluation and the presence of specific collagens (collagen type I and II) via immunofluorescence.

Histological evaluation of collagen deposition was done via Pricosirius Red staining, a dye that stains in red/orange all collagen types present (Fig. S2). Observation via optical microscopy showed that the stain was concentrated mainly on the cell bodies in all samples. As was observed for GAG stains, cells were concentrated on the outside of the scaffolds, encapsulating them (Figures S5, top view column). Higher amounts of collagen were present in differentiation samples as compared to control conditions and also a higher deposition was observed after 28 days than after only 14 days of culture. Samples with $500 \mu \mathrm{m}$ pore size at 90 and $60^{\circ}$ pattern showed the highest deposition of collagens presenting closed pores as compared to the open pores observed for samples at $200 \mu \mathrm{m}$ pore size and $500 \mu \mathrm{m}$ and $30^{\circ}$.

The deposition of specific collagens was evaluated via immunostaining of collagen II (blue) and collagen I (red) on scaffolds cultured in differentiation and control (basal) conditions after 28 days of culture (Fig. 4a). Scaffolds cultured in control media showed a lower amount of cells and presented, still after 28 days of culture, open pores. Only the surface of the fibers was covered with cells. Contrary, samples cultured in differentiation media appeared to be populated, presenting pores fully infiltrated with cells. Large amounts of collagen type II were deposited on the shape of extracellular fibers in samples with a $500 \mu \mathrm{m}$ pore size at $90^{\circ}$ and $60^{\circ}$ pores shape (Fig. 4a, insets). Scaffolds with $200 \mu \mathrm{m}$ pore size revealed the presence of very few cells on the pores of the scaffold and, scaffolds with $500 \mu \mathrm{m}$ and $30^{\circ}$ structure showed few cells invading the pores and only intracellular expression of collagen II. Collagen type I was only present intracellularly, localized on the cytosol of the cells, as shown on the inset figures, for all scaffold types. As control, ATDC5 cells cultured on the traditional pellet format were cryotomed and stained for the same markers showing a similar result, with a larger expression of collagen II than collagen I (Fig. S5).

\subsubsection{Cell invasion and formation of homogeneous tissue}

To study the overall cell invasion and tissue formation within the scaffolds $\mu \mathrm{CT}$ scans were run (Fig. 4b and SI videos S9 - S12).
Scaffolds printed at $500 \mu \mathrm{m}$ and $90^{\circ}$ pattern showed a great cell invasion and deposition of ECM as visualized by the darker fibrous areas present on the core of the scaffold (Fig. 4b). Scaffolds with a smaller pore size of $200 \mu \mathrm{m}$ appeared to be nude, with only some darker areas on the vicinity of the fibers. A high cell invasion was also visualized on scaffolds with $500 \mu \mathrm{m}$ and $60^{\circ}$ pore shape that present the highest connectivity number (Table 2), where cells could be clearly distinguished on the surface of the fibers. Scaffolds with a more tortuous pattern (lower connectivity) such as the ones with pore shapes of $500 \mu \mathrm{m}$ and $30^{\circ}$ presented a lower cell invasion that their counterparts with $500 \mu \mathrm{m}$ pore size and $90^{\circ}$ and $60^{\circ}$ pattern. These results are ascribed to the ease of cell penetration into the scaffolds depending or the tortuosity of the path and the size of the pores.

\subsubsection{Chondrogenic re-differentiation}

The capability of the 3D scaffolds on their different structures to promote re-differentiation of ATDC5 cells was evaluated by RTPCR after 28 days of culture as compared to de-differentiated monolayer cultures (Fig. 5). Cells cultured in differentiation media showed an upregulation of characteristic chondrogenic markers such as Collagen II (6-fold increase) and Sox9 (8-fold increase), while cells cultured in pellet showed a lower upregulation of collagen II (2.3-fold) (Fig. 5). Similarly to the gold standard pellet culture, cells cultured on scaffolds also showed an upregulation of collagen I of 10- to 11-fold that was lower than that of pellets (12fold). However, these cultures also presented a lower expression of RunX2 (1.5 to 2.2- fold increase) than the pellet cultures (5.6fold). Moreover, the collagen II to collagen I gene expression ratio was more than 25 -fold higher in scaffolds than on pellet cultures ( $\sim 5$ vs $\sim 0.2$, respectively), representing a more pronounced chondrogenic differentiation. No significant differences were detected between the scaffolds with different pore architectures, suggesting that this is solely a material effect.

To rule out the effect of the transport of growth factors and molecules responsible for chondrogenic differentiation through the scaffold materials and pellet cultures, we compared the gene expression profile of those cultured in basal conditions (Fig. 6). Overall, the use of basal media showed a very similar trend on the dedifferentiation of ATDC5 cells. The main differences were identified as a lower expression of collagen II and a higher expression of RunX2. However, also a more intense downregulation of collagen $X$ was detected. Cells showed a higher expression of collagen II and a lower expression of collagen I and RunX2 on cells cultured on the scaffolds than on pellet cultures. A collagen II / collagen I ratio of $\sim 0.5$ vs $\sim 0.1$ was measured for cells cultured in scaffolds vs pellet cultures.

\subsubsection{Mechanical properties of tissue-scaffold construct}

The Young،s modulus $(E)$ under compression in liquid and nonequilibrium conditions was measured for the different scaffolds after 14 and 28 days of culture. All scaffolds showed an initial increase of the mechanical properties after 14 days of culture, which is generally taken as an indication of the deposition of ECM by the cells. After 28 days of culture, a decrease of the mechanical properties was measured in all the samples, which we ascribed to an initial degradation of the polymer. The mechanical properties were lower on differentiation media as compared to maintenance media. (Fig. S7). Although a higher amount of ECM was being deposited on the scaffolds on differentiation conditions, the cell number was also higher, possibly creating a fast decrease of the local pH surrounding the cells and therefore the scaffold, with a potential increased degradation of the material. Overall, and in accordance to previously presented data, the Young's modulus of the scaffolds increased with a decreased pore size $(500 \mu \mathrm{m}$ 

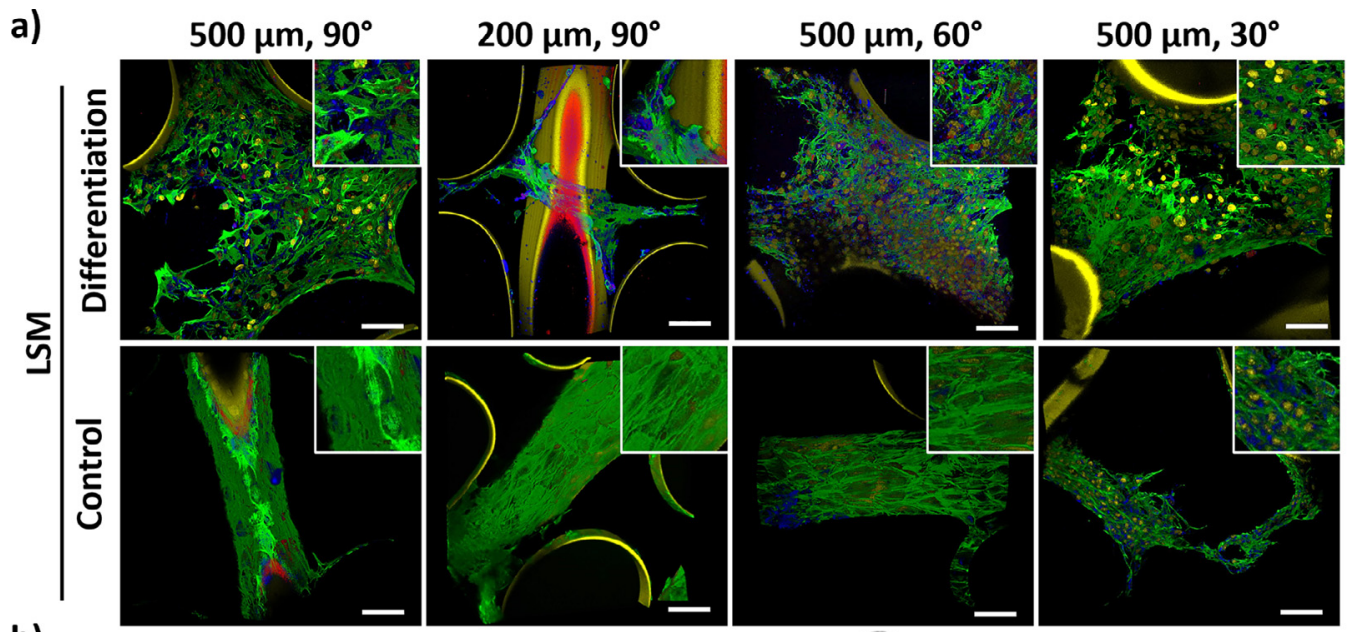

b)
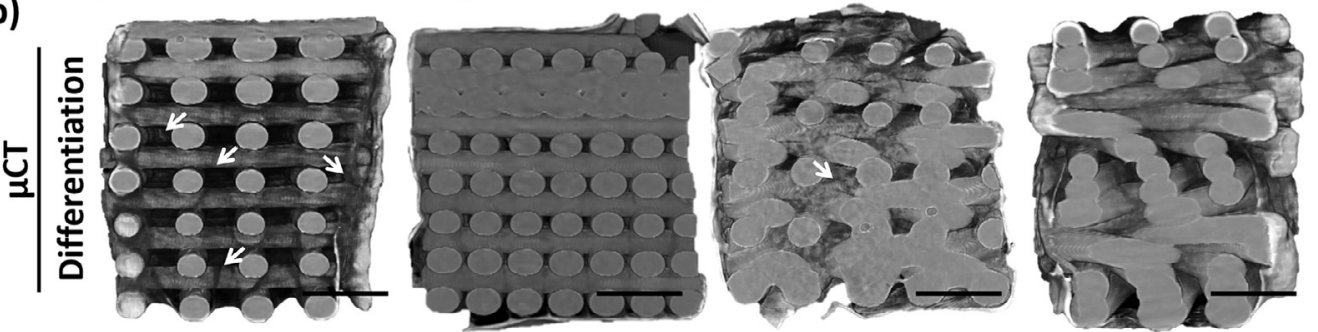

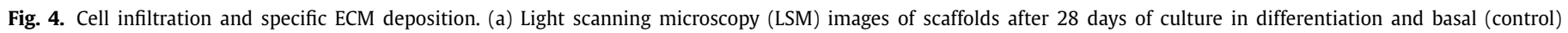

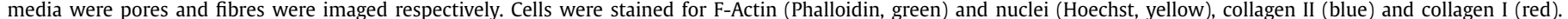

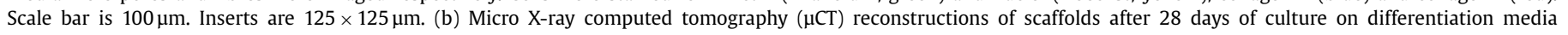

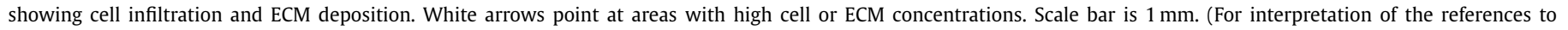
color in this figure legend, the reader is referred to the web version of this article.)

a)

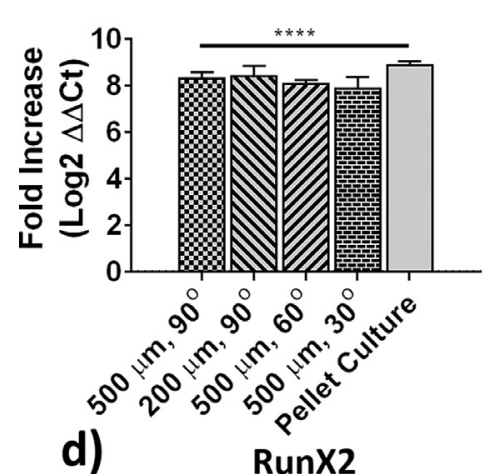

d)

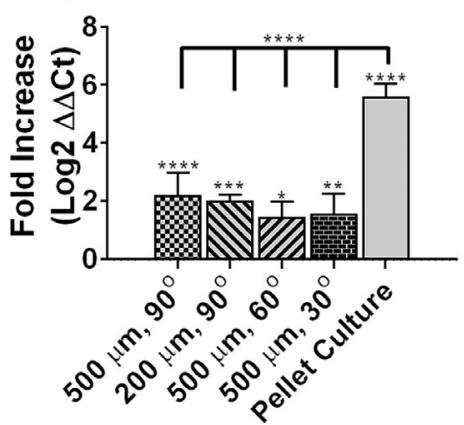

b) Collagen II

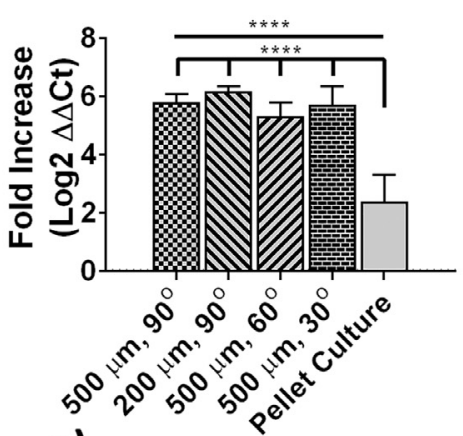

e)

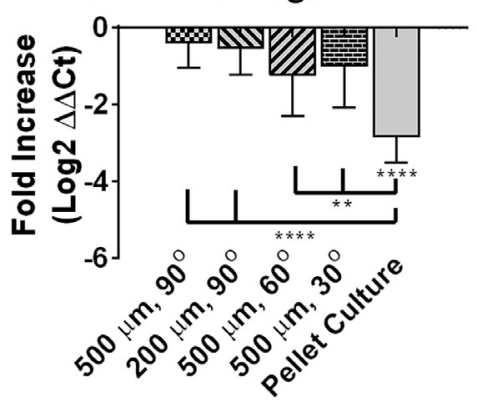

c)

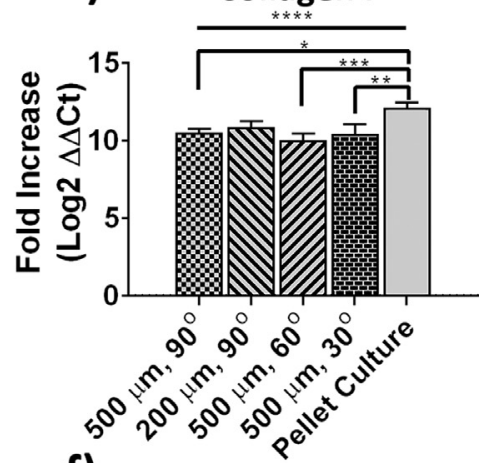

f)

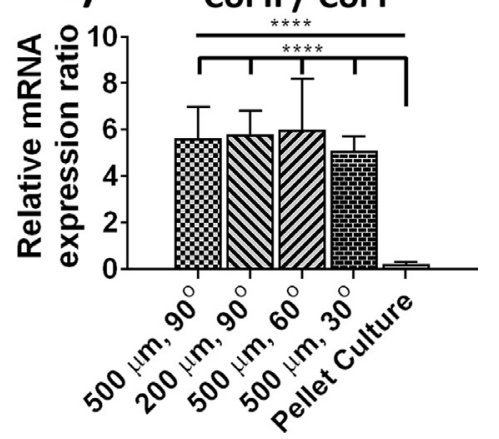

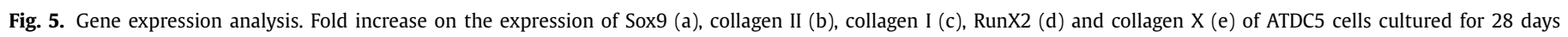

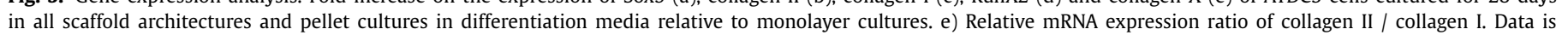
shown as mean $\pm \mathrm{SD}, n=3$. Statistical significance is calculated by two-way ANOVA; $\left({ }^{* * * *}\right) p<0.0001,\left({ }^{* * *}\right) p<0.001,\left({ }^{* *}\right) p<0.01$ and $\left({ }^{*}\right) p<0.1$. 

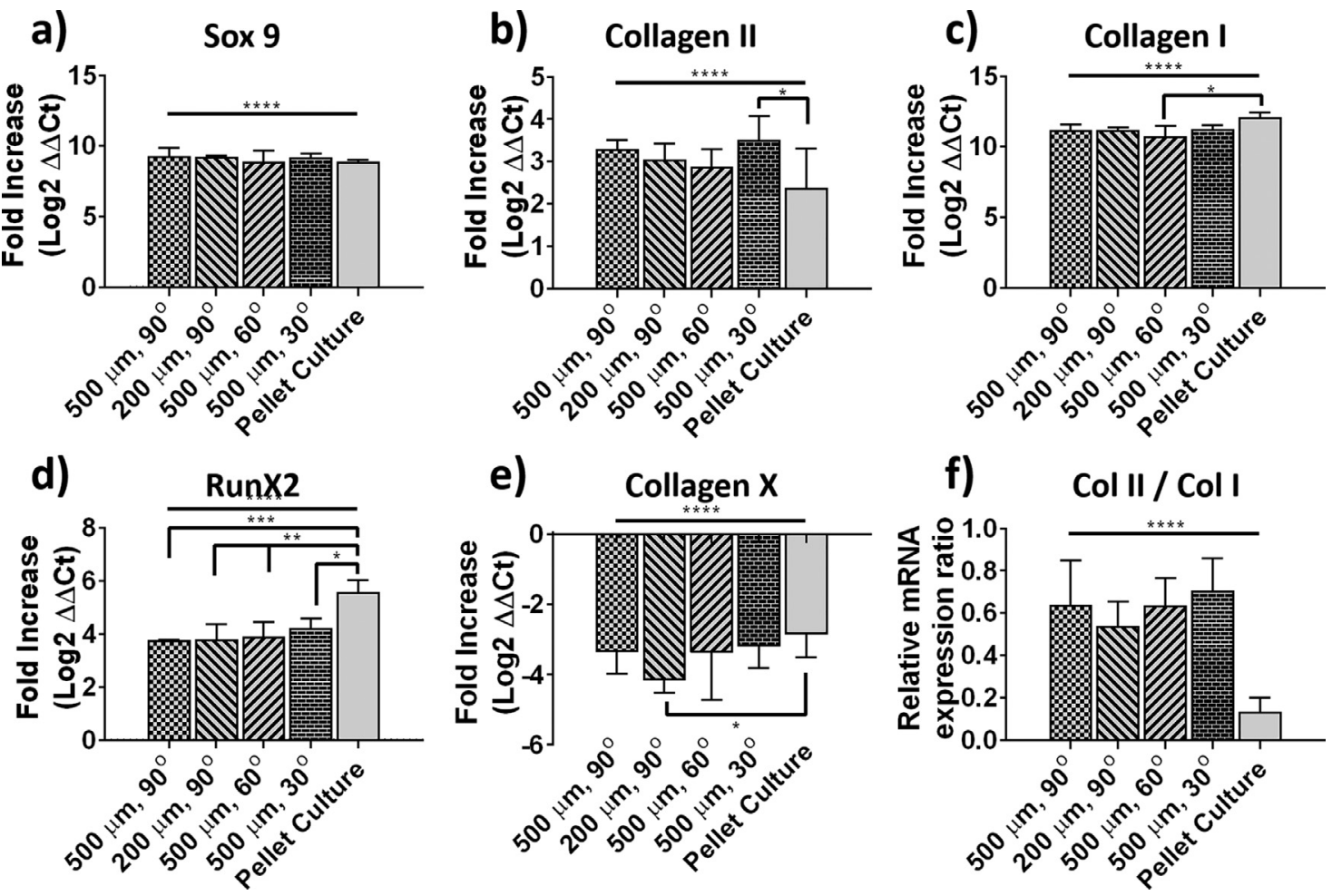

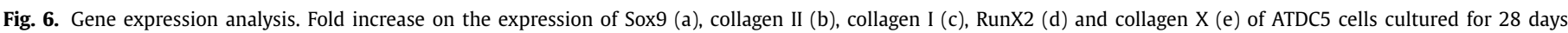

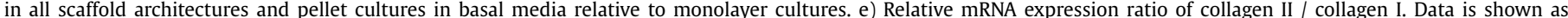
mean $\pm \mathrm{SD}, n=3$. Statistical significance is calculated by two-way ANOVA; $\left({ }^{* * * *}\right) p<0.0001,\left({ }^{* * *}\right) p<0.001,\left({ }^{* *}\right) p<0.01$ and $\left({ }^{*}\right) p<0.1$.

Table 3

Non-equilibrium compressive Young's modulus of cell-scaffold constructs after 14 and 28 days of culture in differentiation media.

\begin{tabular}{llc}
\hline Scaffold architecture & \multicolumn{2}{l}{ Compressive Young's Modulus $(E)(\mathrm{MPa})$} \\
\cline { 2 - 3 } & 14 days & 28 days \\
\hline $500 \mu \mathrm{m}, 90^{\circ}$ & $6 \pm 1$ & $4.6 \pm 0.4$ \\
$200 \mu \mathrm{m}, 90^{\circ}$ & $15 \pm 1$ & $7.3 \pm 0.3$ \\
$500 \mu \mathrm{m}, 60^{\circ}$ & $4.6 \pm 0.7$ & $3.1 \pm 0.7$ \\
$500 \mu \mathrm{m}, 30^{\circ}$ & $3 \pm 1$ & $2.2 \pm 0.1$ \\
\hline
\end{tabular}

vs $200 \mu \mathrm{m})$. Samples at $90^{\circ}$ pore shape presented higher compressive modulus than samples at 60 or $30^{\circ}$ (Table 3). After 28 days of culture all the scaffold architectures presented mechanical properties that are above the ones reported for the native articular cartilage (0.3 - 0.8 MPa in unconfined compression) with values of $4.6 \pm 0.4 ; 7.3 \pm 0.3 ; 3.1 \pm 0.7$ and $2.2 \pm 0.1 \mathrm{MPa}$ for samples $500 \mu \mathrm{m}, 90^{\circ} ; 200 \mu \mathrm{m}, 90^{\circ}, 500 \mu \mathrm{m}, 60^{\circ}$ and $500 \mu \mathrm{m}, 30^{\circ}$; respectively (Table 3 ).

\section{Discussion}

Biodegradable poly(ester)urethanes have shown their potential in soft tissue engineering applications where high resilience is required. However, its exploitation has been limited to solvent-based biofabrication techniques and, only recently its application in additive manufacturing has been reported $[48,49]$. We have successfully optimized the FDM process, resulting in scaffolds with constant molecular weight, and low printing error. Changing solely the pore size and printing pattern we were able to produce scaffolds with compressive $E$ that ranged from 1 to $15 \mathrm{MPa}$, using the same poly (ester urethane) and covering over one order of magnitude. Other studies considering the range of mechanical properties that can be covered by changing the pore shape and size of materials with lower elasticity, i. e. PEOT / PBT and poly(L-lactideco-caprolactone), showed lower tunability with $E$ that ranged from 2.6 to $13.7 \mathrm{MPa}$ and from 0.22 to $0.27 \mathrm{MPa}$, respectively [31,56]. Mikos and co-workers also investigated the effect on compressive mechanical properties of neat PCL scaffolds and its blends with $0-30 \%$ hydroxyapatite (HA) with a fiber spacing that vary from 0.2 to $0.9 \mathrm{~mm}$, resulting in Young's moduli that varied from 100 to $200 \mathrm{MPa}$ independently of the HA concentration [57]. Thus, the combination of elastomeric materials and FDM proved a great tool for the fabrication of scaffolds that could target a great variety of tissues. Moreover, the elastic regime of the PEU scaffolds ranged from 20 to $50 \%$ strain, with increased elastic regime for architectures with decreased pore size. The trend is likely explained by the increased contact area between fibers from adjacent layers as the deposition angle between layers decreases. The soft segment of the PEU used here is synthesized from polycaprolactone (PCL) and polylactic acid (PLA) blocks, traditional materials used for FDM. While presenting high stiffness, PCL and PLA are generally brittle and non-elastic with typical yield strain values of $6-8 \%$ and $2-5 \%$ for PCL and PLA, respectively [37,38].

The application of this elastic PEU for the regeneration of articular cartilage appeared to be successful, resulting in the deposition of an ECM with high amount of GAGs and collagen II, characteristic of hyaline cartilage. Evaluation of the GAG deposition resulted on values up to $8 \mu \mathrm{g}$ after 28 days of culture with higher GAG densities for scaffolds with lowest open pore space. These data are in good agreement with previous findings reported by our group on a study performed with primary bovine chondrocytes on PEOT/PBT additive manufactured scaffolds where a reduced porosity resulted on an increased GAG deposition [58]. On a similar study, culture of ATDC5 cells in additive manufactured scaffolds based on PEOT / PBT copolymer resulted on lower amounts of GAG deposition. After 2 weeks of culture, GAG deposition values of $0.15-0.2 \mu \mathrm{g}$ of $\mathrm{GAG} / \mu \mathrm{g}$ DNA were measured in basal media and of $0.2-0.4 \mu \mathrm{g}$ 
of GAG / $\mu$ g DNA on cells cultured on ITS containing media [59]. These results evidence the potential that PEU scaffolds represent over traditional materials.

Chondrocytes of hyaline cartilage are characterized by the expression of high amounts of collagen II, the transcription factors Sox-9, Sox-5 and Sox-6 and, a low expression of collagen X, collagen I and runt-related transcription factor 2 (RunX2) [10]. The expression of these factors gradually varies along the depth of the tissue until the calcified zone where, hypertrophic chondrocytes express higher amounts of collagen X and collagen I. Monolayer culture of chondrocytes leads to the de-differentiation of the cells that will then express higher amounts of collagen I, collagen $\mathrm{X}$ and RunX2, similarly to hypertrophic chondrocytes. In fact, a ratio of collagen II / collagen I lower than 1 , has been traditionally considered as a marker of cell de-differentiation [60]. Moreover, culture on stiff or 2D substrates generally results on cell spreading, tension and the formation of well-defined actin filaments, which has been traditionally thought to be a non-chondrogenic cell environment leading to the de-differentiation of the cells [61]. Although multiple examples exist on literature of FDM scaffolds for articular cartilage regeneration, these account for mechanical properties that are well above those characteristic of the tissue. And, in many cases, cells within such scaffolds present a phenotypic state characteristic of hypertrophic chondrocytes.

ATDC 5 cells, a teratocacinoma derived cell line, express characteristic markers of hypertrophic chondrocytes when cultured in monolayer but represent a good model for endochondral plate development when cultured in pellet $[15,62,63]$. Collagen II deposition by ATDC5 cells on PEU based FDM scaffolds was evidenced via histological staining, immunofluorescence and gene expression analysis (Fig. S2, 4 and 5) with collagen II / collagen I expression ratios of $\sim 5 ; 25$-fold higher than that measured for pellet cultures. Similar results were reported by Jian and co-workers on $\operatorname{poly}(\epsilon-$ caprolactone) / polytetrahydrofuran urethane (PCL-PTHF) electrospun scaffolds coated with collagen I where human mesenchymal stem cells were cultured for 21 days and showed a collagen II / collagen I ratio of $\sim 6$ [64]. This results is, to the best of our knowledge, the highest reported for cells cultured on FDM scaffolds and highlights the importance of the use of softer elastic materials, more representative of cartilage. Further analysis showed a lower expression of genes characteristic of hypertrophy such as Collagen I, RunX2 and Collagen X in cells cultured in scaffolds than in traditional pellet cultures. This result showed that cells cultured within the scaffolds deposit a matrix characteristic of hyaline cartilage rather than the characteristic evolution towards hypertrophy traditionally observed in-vitro for these and other cell types, and also observed by us on pellet cultures [15,63]. Most importantly, the media composition used in this study is insulin-based, without the use growth factors such as transforming growth factor- $\beta$ (TGF$\beta$ ), that are common for the differentiation of stem cells towards chondrogenic phenotypes. Insulin-based media, without the addition of TGF- $\beta$, has been shown to induce proliferation of ATDC5 cells and high expression of collagen I, X and RunX2. While TGF$\beta$ supplemented media better induced the expression of markers such as collagen II.

We further validated this hypothesis by culturing ATDC5 cells on our scaffolds on basal media showing gene expression profiles more characteristic of resting chondrocytes than those cultured on pellet. These results in differentiation and also in basal conditions suggest that not the 3-dimensional environment, nor the cell culture media used are the unique cause of the de-differentiation of chondrocytes in our scaffolds, but the material itself (either by mechanical or chemical properties) has a positive influence on the process of chondrogenesis. This chondro-inductive potential of PEU is a material feature not observed or published before for other synthetic degradable polymers. Thus, we hypothesize that the out- standing performance of PCL and PLA based PEU as support material enabling cartilage formation is a consequence of the softer and more elastic properties of the polymer.

\section{Conclusion}

All together, we have demonstrated the fabrication of FDM scaffolds of an elastic and biodegradable PEU is possible without inducing a significant degradation of the material. The mechanical properties of these materials can be finely tuned by changing the pore size and architecture of the scaffolds, covering more than one order of magnitude. The elastic limit of the materials thus prepared can be extended from 20 to $50 \%$, much higher than its counterparts, PLA and PCL. Comparison between the different scaffold architectures chosen for this study showed that small pore sizes of $200 \mu \mathrm{m}$ are not adequate for long term culture and results in a decreased cell proliferation and scaffold invasion as observed by LSM images and $\mu \mathrm{CT}$ scans. However, a slightly higher GAG deposition was detected for these pore architectures. Scaffolds with bigger pore sizes of $500 \mu \mathrm{m}$ allowed cell infiltration, matrix deposition and cell de-differentiation. Within this bigger pore size, scaffolds with a $30^{\circ}$ pore architecture and thus a more tortuous (lower connectivity) structure present a lower cell infiltration and GAG deposition than that ones with a $60^{\circ}$ or $90^{\circ}$ structure. In-vitro cartilage engineering with ATDC5 cells resulted on a large deposition of GAGs and the expression of characteristic chondrogenic markers, with a collagen II / collagen I ratio of 5-6. Most importantly, the expression of chondrogenic markers was significantly higher for cells cultured on scaffold materials than on the gold-standard pellet cultures. A detailed analysis of gene expression and matrix deposition by RT-PCR, immunofluorescence and histological analysis in differentiation and basal media revealed that the intrinsic properties of PEU scaffolds materials enhance the cartilage formation and chondrogenic gene expression of cells cultured within as compared to traditional pellet cultures, which presented a rather hypertrophic phenotype. We also proved that the cell infiltration and matrix deposition in scaffolds with a $500 \mu \mathrm{m}$ pore size and $90^{\circ}$ and $60^{\circ}$ pattern was higher than that of scaffolds with smaller pore sizes $(200 \mu \mathrm{m})$ or more tortuous structures $\left(30^{\circ}\right.$ pattern $)$. The mechanical properties of the cell/scaffold constructs with $500 \mu \mathrm{m}$ pore size and $90^{\circ}$ and $60^{\circ}$ pattern showed an initial increase in the compressive Young's modulus after 14 days of culture ascribed to the deposition of neo-tissue, and suffered a slight decrease after 28 days of culture as the material starts to degrade. After 28 days of culture, Young's moduli of 3.1 and 4.6 MPa were measured for the $60^{\circ}$ and $90^{\circ}$ patterns, respectively. Thus, PEU FDM scaffolds fabricated here with $500 \mu \mathrm{m}$ pore size and $90^{\circ}$ and $60^{\circ}$ pattern appear as ideal candidates for the in $\bullet$ vitro formation of neo-cartilage and potential regeneration of articular cartilage defects.

\section{Declaration of Competing Interest}

The authors declare that they have no known competing financial interests or personal relationships that could have appeared to influence the work reported in this paper.

\section{Acknowledgements}

The authors thank Martin Tooren for the material synthesis. This work was supported by the ERC starting grant "Cell Hybridge" under the Horizon2020 framework program (Grant \# 637308)

\section{Author disclosure statement}

We have no competing financial interests to declare. 


\section{Data availability}

All data supporting the findings of this study are available from the corresponding authors upon request.

\section{Supplementary materials}

Supplementary material associated with this article can be found, in the online version, at doi:10.1016/j.actbio.2019.11.041.

\section{References}

[1] K.A. Athanasiou, E.M. Darling, J.C. Hu, Articular cartilage tissue engineering, Synth. Lect. Tissue Eng. 1 (1) (2009) 1-182.

[2] K. Messner, J. Gillquist, Cartilage repair: a critical review, Acta Orthop. 67 (5) (1996) 523-529.

[3] G.D. Smith, G. Knutsen, J.B. Richardson, A clinical review of cartilage repair techniques, J. Bone Joint Surg. Br. 87B (4) (2005) 445-449.

[4] D.J. Huey, J.C. Hu, K.A. Athanasiou, Unlike bone, cartilage regeneration remains elusive, Science 338 (6109) (2012) 917-921.

[5] S. Camarero-Espinosa, B. Rothen-Rutishauser, E.J. Foster, C. Weder, Articular cartilage: from formation to tissue engineering, Biomater. Sci. 4 (5) (2016) 734-767.

[6] S. Camarero-Espinosa, J. Cooper-White, Tailoring biomaterial scaffolds for osteochondral repair, Int. J. Pharm. 523 (2) (2017) 476-489

[7] E.A. Makris, A.H. Gomoll, K.N. Malizos, J.C. Hu, K.A. Athanasiou, Repair and tis sue engineering techniques for articular cartilage, Nat. Rev. Rheumatol. 11 (1) (2015) 21-34.

[8] N.P. Cohen, R.J. Foster, V.C. Mow, Composition and dynamics of articular cartilage: structure, function, and maintaining healthy state, J. Orthop. Sports Phys. Therapy 28 (4) (1998) 203-215.

[9] A. Maroudas, H. Muir, J. Wingham, Correlation of fixed negative charge with glycosaminoglycan content of human articular cartilage, Biochim. Biophys. Acta 177 (3) (1969) 492-500

[10] G. Karsenty, Chapter 26 - Cell Differentiation in the skeleton, in: R.L.G.H.M.P.D.T.T. Wilmut (Ed.), Essentials of Stem Cell Biology, (2nd Edition), Academic Press, San Diego, 2009, pp. 223-226.

[11] C. Loebel, N. Broguiere, M. Alini, M. Zenobi-Wong, D. Eglin, Microfabrication of photo-cross-linked hyaluronan hydrogels by Single- and Two-Photon tyramine oxidation, Biomacromolecules 16 (9) (2015) 2624-2630.

[12] K.W.M. Boere, M.M. Blokzijl, J. Visser, J.E.A. Linssen, J. Malda, W.E. Hennink, T. Vermonden, Biofabrication of reinforced 3D-scaffolds using two-component hydrogels, J. Mater. Chem. B 3 (46) (2015) 9067-9078.

[13] R. Gauvin, R. Parenteau-Bareil, M.R. Dokmeci, W.D. Merryman, A. Khademhosseini, Hydrogels and microtechnologies for engineering the cellular microenvironment, Wiley Interdiscip. Rev. Nanomed. Nanobiotechnol. 4 (3) (2012) $235-246$.

[14] B.K. Babur, P. Ghanavi, P. Levett, W.B. Lott, T. Klein, J.J. Cooper-White, R. Crawford, M.R. Doran, The interplay between chondrocyte redifferentiation pellet size and oxygen concentration, PLoS One 8 (3) (2013) e58865.

[15] Y. Yao, Y. Wang, ATDC5: an excellent in vitro model cell line for skeletal development, J. Cell. Biochem. 114 (6) (2013) 1223-1229.

[16] W. Zhao, X. Jin, Y. Cong, Y. Liu, J. Fu, Degradable natural polymer hydrogels for articular cartilage tissue engineering, J. Chem. Technol. Biotechnol. 88 (3) (2013) 327-339.

[17] M. Keeney, J.H. Lai, F. Yang, Recent progress in cartilage tissue engineering, Curr. Opin. Biotechnol. 22 (5) (2011) 734-740.

[18] D.W. Hutmacher, Scaffolds in tissue engineering bone and cartilage, Biomaterials 21 (24) (2000) 2529-2543.

[19] I.L. Kim, C.G. Pfeifer, M.B. Fisher, V. Saxena, G.R. Meloni, M.Y. Kwon, M. Kim, D.R. Steinberg, R.L. Mauck, J.A. Burdick, Fibrous scaffolds with varied fiber chemistry and growth factor delivery promote repair in a porcine cartilage defect model, Tissue Eng. Part A 21 (21-22) (2015) 2680-2690.

[20] J. Coburn, M. Gibson, P.A. Bandalini, C. Laird, H.-.Q. Mao, L. Moroni, D. Seliktar, J. Elisseeff, Biomimetics of the extracellular matrix: an integrated three-dimensional fiber-hydrogel composite for cartilage tissue engineering, Smart Struct. Syst. 7 (3) (2011) 213-222.

[21] J. Visser, F.P.W. Melchels, J.E. Jeon, E.M. van Bussel, L.S. Kimpton, H.M. Byrne, W.J.A. Dhert, P.D. Dalton, D.W. Hutmacher, J. Malda, Reinforcement of hydrogels using three-dimensionally printed microfibres, Nat. Commun. 6 (2015) 6933.

[22] I.C. Liao, F.T. Moutos, B.T. Estes, X. Zhao, F. Guilak, Composite three-dimensional woven scaffolds with interpenetrating network hydrogels to create functional synthetic articular cartilage, Adv. Funct. Mater. 23 (47) (2013) 5833-5839.

[23] F.T. Moutos, L.E. Freed, F. Guilak, A biomimetic three-dimensional woven composite scaffold for functional tissue engineering of cartilage, Nat. Mater. 6 (2) (2007) 162-167

[24] F.T. Moutos, F. Guilak, Functional properties of cell-seeded three-dimensionally woven poly(epsilon-caprolactone) scaffolds for cartilage tissue engineering, Tissue Eng. Part A 16 (4) (2010) 1291-1301.

[25] P.K. Valonen, F.T. Moutos, A. Kusanagi, M.G. Moretti, B.O. Diekman, J.F. Welter, A.I. Caplan, F. Guilak, L.E. Freed, In vitro generation of mechanically functional cartilage grafts based on adult human stem cells and 3D-woven poly( $\varepsilon$-caprolactone) scaffolds, Biomaterials 31 (8) (2010) 2193-2200.

[26] J. Elisseeff, K. Anseth, D. Sims, W. McIntosh, M. Randolph, M. Yaremchuk, R. Langer, Transdermal photopolymerization of poly(ethylene oxide)-based injectable hydrogels for tissue-engineered cartilage, Plast. Reconstr. Surg. 104 (4) (1999) 1014-1022.

[27] J. Elisseeff, W. McIntosh, K. Anseth, S. Riley, P. Ragan, R. Langer, Photoencapsulation of chondrocytes in poly(ethylene oxide)-based semi-interpenetrating networks, J. Biomed. Mater. Res. 51 (2) (2000) 164-171.

[28] S. Camarero-Espinosa, B. Rothen-Rutishauser, C. Weder, E.J. Foster, Directed cell growth in multi-zonal scaffolds for cartilage tissue engineering, Biomaterials 74 (2016) 42-52.

[29] A. Thorvaldsson, H. Stenhamre, P. Gatenholm, P. Walkenstrom, Electrospinning of highly porous scaffolds for cartilage regeneration, Biomacromolecules 9 (3) (2008) 1044-1049.

[30] R. Zheng, H.C. Duan, J.X. Xue, Y. Liu, B. Feng, S.F. Zhao, Y.Q. Zhu, Y. Liu, A.J. He W.J. Zhang, W. Liu, Y.L. Cao, G.D. Zhou, The influence of gelatin/pcl ratio and 3-D construct shape of electrospun membranes on cartilage regeneration, Biomaterials 35 (1) (2014) 152-164.

[31] L. Moroni, J.R. de Wijn, C.A. van Blitterswijk, 3D fiber-deposited scaffolds for tissue engineering: influence of pores geometry and architecture on dynamic mechanical properties, Biomaterials 27 (7) (2006) 974-985.

[32] A. Di Luca, I. Lorenzo-Moldero, C. Mota, A. Lepedda, D. Auhl, C. Van Blitterswijk, L. Moroni, Tuning cell differentiation into a 3D scaffold presenting a pore shape gradient for osteochondral regeneration, Adv. Healthc. Mater. 5 (14) (2016) 1753-1763.

[33] X.J. Xin, M. Hussain, J.J. Mao, Continuing differentiation of human mesenchymal stem cells and induced chondrogenic and osteogenic lineages in electrospun PLGA nanofiber scaffold, Biomaterials 28 (2) (2007) 316325.

[34] J.K. Sherwood, S.L. Riley, R. Palazzolo, S.C. Brown, D.C. Monkhouse, M. Coates, L.G. Griffith, L.K. Landeen, A. Ratcliffe, A three-dimensional osteochondral composite scaffold for articular cartilage repair, Biomaterials 23 (24) (2002) 4739-4751.

[35] C. Chung, J.A. Burdick, Engineering cartilage tissue, Adv. Drug Deliv. Rev. 60 (2) (2008) 243-262.

[36] N.V. Mekhileri, K.S. Lim, G.C.J. Brown, I. Mutreja, B.S. Schon, G.J. Hooper, T.B.F. Woodfield, Automated 3D bioassembly of micro-tissues for biofabrication of hybrid tissue engineered constructs, Biofabrication 10 (2) (2018).

[37] I. Zein, D.W. Hutmacher, K.C. Tan, S.H. Teoh, Fused deposition modeling of novel scaffold architectures for tissue engineering applications, Biomaterials 23 (4) (2002) 1169-1185

[38] J.M. Chacón, M.A. Caminero, E. García-Plaza, P.J. Núñez, Additive manufacturing of PLA structures using fused deposition modelling: effect of process parameters on mechanical properties and their optimal selection, Mater. Des. 124 (2017) 143-157.

[39] I. Dresing, S. Zeiter, J. Auer, M. Alini, D. Eglin, Evaluation of a press-fit osteochondral poly(ester-urethane) scaffold in a rabbit defect model, J. Mater. Sci. Mater. Med. 25 (7) (2014) 1691-1700.

[40] T. Courtney, M.S. Sacks, J. Stankus, J. Guan, W.R. Wagner, Design and analysis of tissue engineering scaffolds that mimic soft tissue mechanical anisotropy, Biomaterials 27 (19) (2006) 3631-3638.

[41] L. Soletti, Y. Hong, J. Guan, J.J. Stankus, M.S. El-Kurdi, W.R. Wagner, D.A. Vorp, A bilayered elastomeric scaffold for tissue engineering of small diameter vascular grafts, Acta Biomater. 6 (1) (2010) 110-122.

[42] L. Wang, W. Cao, X. Wang, P. Li, J. Zhou, G. Zhang, X. Li, X. Xing, Biodegradable silver-loaded polycation modified nanodiamonds/polyurethane scaffold with improved antibacterial and mechanical properties for cartilage tissue repairing, J. Mater. Sci. Mater. Med. 30 (4) (2019) 41.

[43] O.F.W. Gardner, G. Musumeci, A.J. Neumann, D. Eglin, C.W. Archer, M. Alini, M.J. Stoddart, Asymmetrical seeding of MSCs into fibrin-poly(ester-urethane) scaffolds and its effect on mechanically induced chondrogenesis, J. Tissue Eng. Regen. Med. 11 (10) (2017) 2912-2921.

[44] S.-.L. Chia, K. Gorna, S. Gogolewski, M. Alini, Biodegradable elastomeric polyurethane membranes as chondrocyte carriers for cartilage repair, Tissue Eng. 12 (7) (2006) 1945-1953.

[45] K. Gorna, S. Gogolewski, Novel biodegradable polyurethanes for medical applications, in: C.M. Agrawal, J. Parr, S. Lin (Eds.), ASTM International, West Conshohocken, PA, 2000, pp. 39-57.

[46] S. Grad, L. Kupcsik, K. Gorna, S. Gogolewski, M. Alini, The use of biodegradable polyurethane scaffolds for cartilage tissue engineering: potential and limitations, Biomaterials 24 (28) (2003) 5163-5171.

[47] Z. Li, L. Kupcsik, S.-.J. Yao, M. Alini, M.J. Stoddart, Chondrogenesis of human bone marrow mesenchymal stem cells in fibrin-polyurethane composites, Tissue Eng. Part A 15 (7) (2009) 1729-1737.

[48] K.-.C. Hung, C.-.S. Tseng, L.-.G. Dai, S.-h. Hsu, Water-based polyurethane 3D printed scaffolds with controlled release function for customized cartilage tissue engineering, Biomaterials 83 (2016) 156-168.

[49] K.-.C. Hung, C.-.S. Tseng, S.-h. Hsu, Synthesis and 3D printing of biodegradable polyurethane elastomer by a water-based process for cartilage tissue engineering applications, Adv. Healthc. Mater. 3 (10) (2014) 1578-1587.

[50] J.H. de Groot, C.J. Spaans, F.G. Dekens, A.J. Pennings, On the role of aminolysis and transesterification in the synthesis of $\varepsilon$-caprolactone and L-lactide based polyurethanes, Polym. Bull. 41 (3) (1998) 299-306.

[51] L.A. Feldkamp, L.C. Davis, J.W. Kress, Practical cone-beam algorithm, J. Opt. Soc. Am. A 1 (6) (1984) 612-619. 
[52] J.E. Siegel, D.C. Erb, I.M. Ehrenberg, P. Jain, S.E. Sarma, Local viscosity control printing for high-throughput additive manufacturing of polymers, 3D Print. Addit. Manuf. 3 (4) (2016) 252-261.

[53] K.A. Athanasiou, M.P. Rosenwasser, J.A. Buckwalter, T.I. Malinin, V.C. Mow, Interspecies comparisons of in-situ intrinsic mechanical-properties of distal femoral cartilage, J. Orthop. Res. 9 (3) (1991) 330-340.

[54] R.M. Schinagl, D. Gurskis, A.C. Chen, R.L. Sah, Depth-dependent confined compression modulus of full-thickness bovine articular cartilage, J. Orthop. Res. 15 (4) (1997) 499-506.

[55] R.K. Korhonen, M.S. Laasanen, J. Töyräs, J. Rieppo, J. Hirvonen, H.J. Helminen, J.S. Jurvelin, Comparison of the equilibrium response of articular cartilage in unconfined compression, confined compression and indentation, J. Biomech. 35 (7) (2002) 903-909.

[56] Y. Sun, A. Finne-Wistrand, A.-.C. Albertsson, Z. Xing, K. Mustafa, W.J. Hendrikson, D.W. Grijpma, L. Moroni, Degradable amorphous scaffolds with enhanced mechanical properties and homogeneous cell distribution produced by a three-dimensional fiber deposition method, J. Biomed. Mater. Res. Part A 100A (10) (2012) 2739-2749.

[57] S.M. Bittner, B.T. Smith, L. Diaz-Gomez, C.D. Hudgins, A.J. Melchiorri, D.W. Scott, J.P. Fisher, A.G. Mikos, Fabrication and mechanical characterization of 3D printed vertical uniform and gradient scaffolds for bone and osteochondral tissue engineering, Acta Biomater. 90 (2019) 37-48.
[58] J.A.A. Hendriks, L. Moroni, J. Riesle, J.R. de Wijn, C.A. van Blitterswijk, The effect of scaffold-cell entrapment capacity and physico-chemical properties on cartilage regeneration, Biomaterials 34 (17) (2013) 4259-4265.

[59] P. Cools, C. Mota, I. Lorenzo-Moldero, R. Ghobeira, N. De Geyter, L. Moroni, R. Morent, Acrylic acid plasma coated 3D scaffolds for cartilage tissue engineering applications, Sci. Rep. 8 (2018) 3830.

[60] M. S, H. M., T. M., V. V., S. W., Changes in the ratio of type-I and type-II collagen expression during monolayer culture of human chondrocytes, J. Bone Joint Surg. Br. 86-B (2) (2004) 286-295 volume.

61] A. Woods, G.Y. Wang, F. Beier, Regulation of chondrocyte differentiation by the actin cytoskeleton and adhesive interactions, J. Cell. Physiol. 213 (1) (2007) $1-8$.

62] P.T. Newton, K.A. Staines, L. Spevak, A.L. Boskey, C.C. Teixeira, V.E. Macrae, A.E. Canfield, C. Farquharson, Chondrogenic ATDC5 cells: an optimised model for rapid and physiological matrix mineralisation, Int. J. Mol. Med. 30 (5) (2012) 1187-1193.

[63] C. Shukunami, K. Ishizeki, T. Atsumi, Y Ohta, F Suzuki, Y Hiraki, Cellular hypertrophy and calcification of embryonal carcinoma-derived chondrogenic cell line ATDC5 in vitro, J. Bone Miner. Res. 12 (8) (1997) 1174-1188.

64] T. Jiang, D. Kai, S. Liu, X. Huang, S. Heng, J. Zhao, B.Q.Y. Chan, X.J. Loh, Y. Zhu, C. Mao, L. Zheng, Mechanically cartilage-mimicking poly(PCL-PTHF urethane)/collagen nanofibers induce chondrogenesis by blocking NF-kappa b signaling pathway, Biomaterials 178 (2018) 281-292. 